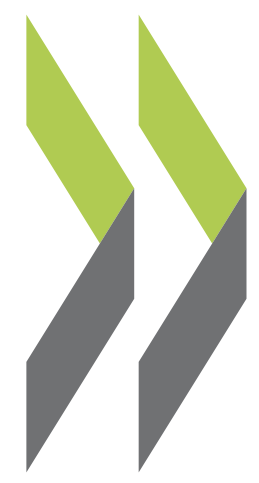

OECD Economics Department Working Papers No. 1318

\author{
Costa Rica: Boosting \\ productivity to sustain \\ income convergence
} Mauro Pisu 
Organisation de Coopération et de Développement Économiques

Organisation for Economic Co-operation and Development

22-Jul-2016

ECONOMICS DEPARTMENT

English - Or. English

COSTA RICA: BOOSTING PRODUCTIVITY TO SUSTAIN INCOME CONVERGENCE

ECONOMICS DEPARTMENT WORKING PAPERS No. 1318

\section{By Mauro Pisu}

OECD Working Papers should not be reported as representing the official views of the OECD or of its member countries. The opinions expressed and arguments employed are those of the author(s).

Authorised for publication by Robert Ford, Deputy Director, Country Studies Branch, Economics Department.

All Economics Department Working Papers are available at www.oecd.org/eco/workingpapers

JT03399434

Complete document available on OLIS in its original format

This document and any map included herein are without prejudice to the status of or sovereignty over any territory, to the delimitation of international frontiers and boundaries and to the name of any territory, city or area. 
OECD Working Papers should not be reported as representing the official views of the OECD or of its member countries. The opinions expressed and arguments employed are those of the author(s).

Working Papers describe preliminary results or research in progress by the author(s) and are published to stimulate discussion on a broad range of issues on which the OECD works.

Comments on Working Papers are welcomed, and may be sent to OECD Economics Department, 2 rue André-Pascal, 75775 Paris Cedex 16, France, or by e-mail to eco.contact@oecd.org.

All Economics Department Working Papers are available at www.oecd.org/eco/workingpapers

This document and any map included herein are without prejudice to the status of or sovereignty over any territory, to the delimitation of international frontiers and boundaries and to the name of any territory, city or area.

The statistical data for Israel are supplied by and under the responsibility of the relevant Israeli authorities. The use of such data by the OECD is without prejudice to the status of the Golan Heights, East Jerusalem and Israeli settlements in the West Bank under the terms of international law.

Latvia was not an OECD member at the time of preparation of this paper. Accordingly, Latvia is not included in the list of OECD countries and is not included in the area totals.

\section{(c) OECD (2016)}

You can copy, download or print OECD content for your own use, and you can include excerpts from OECD publications, databases and multimedia products in your own documents, presentations, blogs, websites and teaching materials, provided that suitable acknowledgment of OECD as source and copyright owner is given. All requests for commercial use and translation rights should be submitted to rights@oecd.org 
ECO/WKP(2016)42

\section{ABSTRACT/RÉSUMÉ}

\section{Costa Rica: Boosting productivity to sustain income convergence}

In the latest 30 years, Costa Rica's real GDP per capita has more than doubled, driven by increasing labour utilisation. Labour productivity has instead stagnated at around 30\% of the more advanced OECD countries. Productivity growth has been lacklustre despite the opening up of markets to international competition and large FDI inflows. Several obstacles continue to hamper the development of domestic firms and markets. They have fostered a dual speed economy characterised, on the one hand, by an innovative, productive and export oriented FDI sector - increasingly focussing on high value added sectors - and, on the other hand, a domestic sector - dominated by small firms and focused on traditional industries - that is neither innovative nor very productive. Boosting national productivity to sustain the convergence process towards OECD countries living standards will hinge on creating the right conditions for domestic firms to thrive and become more innovative and productive, while maintaining the longstanding commitment to open international markets and investment. To make this happens the government should: 1) encourage innovation and improving links between domestic and foreign firms by better enforcing and implementing intellectual property rights, shifting public R\&D spending towards tertiary education institutions, and improving the coordination of public programmes promoting innovation of local firms and linkages with foreign affiliates; 2) strengthen competition in product markets and ease access to finance for SMEs by eliminating anti-trust exemptions, empowering the competition commission and giving it more independence, reducing barriers to entrepreneurship, ameliorating the corporate governance of state-owned enterprises and creating a level-playing fields between state-owned and private banks; 3 ) enhance the institutional and legal framework of the transport and other infrastructure sectors by reducing the number of agencies involved in policy development and project executions, and establishing an institutional framework to reduce policy uncertainty and attract more private investment.

This Working Paper relates to the 2016 OECD Economic Assessment of Costa Rica (www.oecd.org/eco/surveys/economic-survey-costa-rica.htm).

JEL classification: O00; O30; O33; O38; F20; G20; G28; H10; H40; H54; L40; L91; L98.

Keywords: productivity, innovation, technical change, research and development, transport infrastructure, competition, anti-trust, foreign direct investment, access to finance.

$* * * * * * * * * * * * * * * * * * * * * * * * * * * * * *$

\section{Costa Rica: Stimuler la productivité pour soutenir la convergence des revenus}

Dans les dernières 30 années, le PIB réel par habitant du Costa Rica a plus que doublé, grâce à une utilisation croissante du travail. La productivité du travail a stagné autour de $30 \%$ des pays les plus avancés de l'OCDE. La croissance de la productivité a été terne, malgré l'ouverture des marchés à la concurrence internationale et de grandes entrées d'IDE. Plusieurs obstacles continuent d'entraver le développement des entreprises et des marchés intérieurs. Ils ont favorisé une économie à deux vitesses caractérisée, d'une part, par un secteur de l'IDE innovateur, productif et orienté vers l'exportation - se concentrant de plus en plus sur les secteurs à forte valeur ajoutée - et, d'autre part, un secteur domestique - dominé par les petites entreprises et concentré sur les industries traditionnelles - qui ne sont ni innovantes, ni très productives. 
Stimuler la productivité nationale pour soutenir le processus de convergence vers des pays de l'OCDE le niveau de vie dépendra de la création des conditions pour les entreprises nationales de se développer et de devenir plus innovantes et productives, tout en maintenant l'engagement de longue date pour ouvrir les marchés et les investissements internationaux. Pour que cela arrive, le gouvernement devrait: 1) encourager l'innovation et l'amélioration des liens entre les entreprises nationales et étrangères par une meilleure application et par la mise en œuvre des droits de propriété intellectuelle, en déplaçant les dépenses de R\&D vers les établissements d'enseignement supérieur, et par l'amélioration de la coordination des programmes publics de promotion de l'innovation des entreprises locales et des liens avec des sociétés étrangères affiliées; 2) renforcer la concurrence sur les marchés de produits et de faciliter l'accès au financement pour les PME en éliminant les exemptions anti-trust, habilitant la commission de la concurrence et en lui donnant plus d'indépendance, de réduire les obstacles à l'entrepreneuriat, améliorer la gouvernance des entreprises publiques et la création d'une concurrence equitable entre les banques publiques et privées; 3 ) renforcer le cadre institutionnel et juridique du transport et d'autres secteurs de l'infrastructure, en réduisant le nombre d'organismes impliqués dans les exécutions de développement des politiques et des projets, et l'établissement d'un cadre institutionnel pour réduire l'incertitude politique et d'attirer davantage d'investissements privés.

Ce Document de travail se rapporte à l'Étude économique de l'OCDE de la Costa Rica 2016 (www.oecd.org/fr/eco/etudes/etude-economique-costa-rica.htm).

Classification JEL: O00; O30; O33; O38; F20; G20; G28; H10; H40; H54; L40; L91; L98.

Mots clés: productivité, innovation, changement technique, recherche et le développement, infrastructures de transport, concurrence, autorité de la concurrence, investissement étranger direct, accès au financement, 


\section{TABLE OF CONTENTS}

Costa Rica: Boosting productivity to sustain income convergence ...........................................................

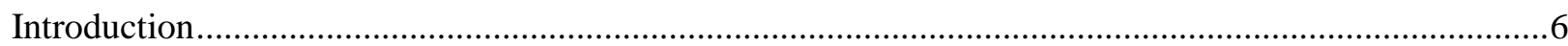

Open markets and foreign direct investment have served the country well ............................................ 8

Raising productivity will require a whole of government approach...................................................13

Enhancing links between the foreign and domestic firms and encouraging innovation ...........................13

Improving coordination between innovation and foreign-domestic linkages programmes ...................17

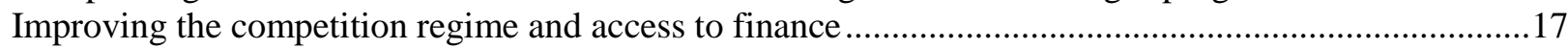

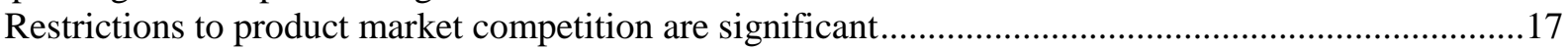

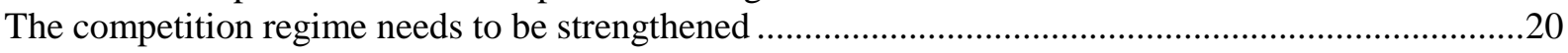

Boosting access to credit through stronger competition in the banking sector ....................................24

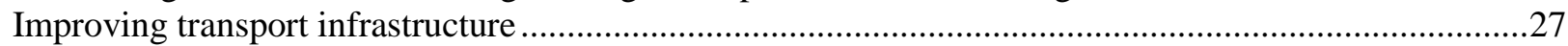

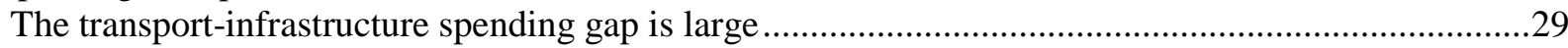

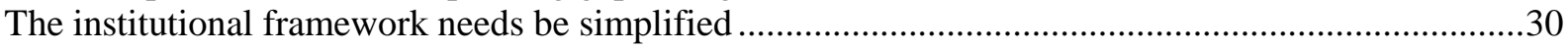

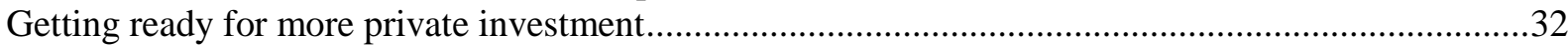

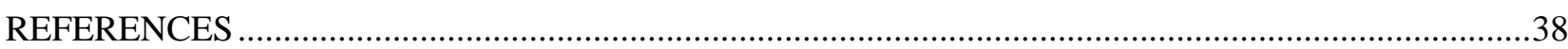

\section{Tables}

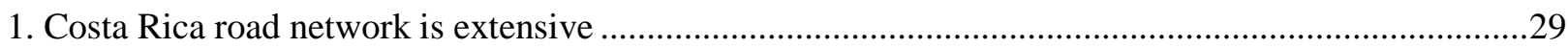

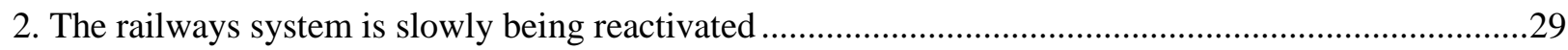

3. The transports sector suffers from institutional fragmentation ..........................................................33

4. OECD Principles for Private Sector Participation in Infrastructure and Costa Rica's practices .............35

\section{Figures}

1. Labour productivity growth is slowing down convergence in GDP per capita ....................................

2. Low labour productivity growth is mostly attributable to sluggish multifactor productivity growth......7

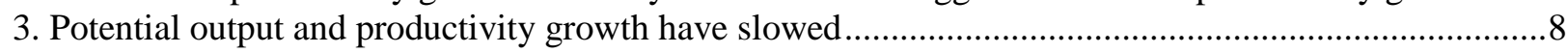

4. Costa Rica has an attractive FDI regime but could do better............................................................... 10

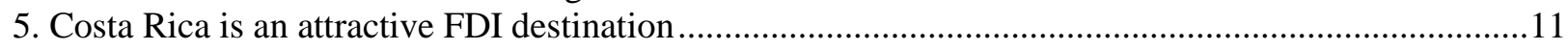

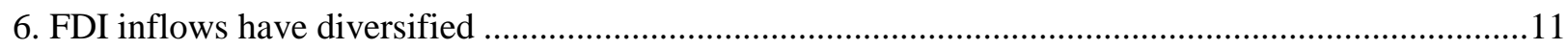

7. Free trade zones have contributed to Costa Rica export performance .................................................12

8. Labour productivity differences between firms in and outside free trade zone are large .....................14

9. Research and development (R\&D) activities are low ....................................................................15

10. Costa Rica has low patent applications compared with OECD countries...........................................16

11. Most relevant instruments of public funding of business R\&D.....................................................16

12. There is scope to ease regulation in product markets ....................................................................18

13.. State controls and barriers to entrepreneurship restrict competition...............................................19

14. The telecommunications sector has expanded since opening up to competition .................................21

15. COPROM has little resources compared with other competition authorities in the region.................22

16. Industry electricity tariffs are higher than in most OECD countries..............................................23

17. High banking interest rate spreads curtail credit availability ...........................................................25

18. State-owned banks are less efficient than private banks and pay higher average wage .....................26

19. There is scope to improve the quality of transport infrastructure …................................................28

20. Transport infrastructure spending has been below OECD average …...............................................30

\section{Boxes}

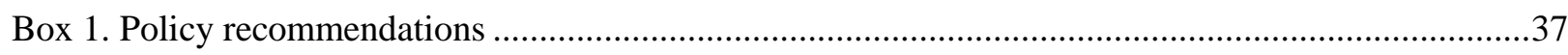




\title{
Costa Rica: Boosting productivity to sustain income convergence
}

\author{
By Mauro Pisu ${ }^{1}$
}

\section{Introduction}

In the latest 30 years, Costa Rica's real GDP per capita has more than doubled, driven by increasing labour utilisation. Labour productivity has instead stagnated at around $30 \%$ of the more advanced OECD countries. Productivity growth has been lacklustre despite the opening up of markets to international competition and large FDI inflows. Several obstacles continue to hamper the development of domestic firms and markets. They have fostered a dual speed economy characterised, on the one hand, by an innovative, productive and export oriented FDI sector - increasingly focussing on high value added sectors - and, on the other hand, a domestic sector - dominated by small firms and focused on traditional industries - that is neither innovative nor very productive. Boosting national productivity to sustain the convergence process towards OECD countries living standards will hinge on creating the right conditions for domestic firms to thrive and become more innovative and productive, while maintaining the longstanding commitment to open international markets and investment. To make this happens the government should: 1) encourage innovation and improving links between domestic and foreign firms by better enforcing and implementing intellectual property rights, shifting public R\&D spending towards tertiary education institutions, and improving the coordination of public programmes promoting innovation of local firms and linkages with foreign affiliates; 2) strengthen competition in product markets and ease access to finance for SMEs by eliminating anti-trust exemptions, empowering the competition commission and giving it more independence, reducing barriers to entrepreneurship, ameliorating the corporate governance of state-owned enterprises and creating a level-playing fields between state-owned and private banks; 3 ) enhance the institutional and legal framework of the transport and other infrastructure sectors by reducing the number of agencies involved in policy development and project executions, and establishing an institutional framework to reduce policy uncertainty and attract more private investment.

Over the past 30 years, Costa Rica' GDP per capita has more than doubled, narrowing the gap with the upper half OECD countries (Figure 1). Despite these gains, Costa Rica's GDP per capita, at USD 15 000, is still about one third of that of the upper half of OECD countries, similarly to Brazil and South Africa but higher than Colombia and China. Higher GDP per capita has been driven by increasing labour utilisation, which is now at the same level with that of the more advanced countries. By contrast, labour productivity has stagnated at around $30 \%$ of the labour-productivity average of the more advanced OECD countries.

1. Mauro Pisu (Mauro.PISU@oecd.org ) is Senior Economist in the OECD Economics Department. The author would like to thank OECD colleagues: Daniel Blume, Directorate for Financial and Enterprise Affairs, Antonio Capobianco, Directorate for Financial and Enterprise Affairs, Robert Ford, Alberto Gonzalez Pandiella, Patrick Lenain and Alvaro Pereira, Economics Department, Dirk Pilat, Directorate for Science, Technology and Innovation, Adolfo Rodriguez-Vargas (Costa Rica), Federico Villalobos, economist specialized in infrastructure for valuable discussions and feedback on earlier drafts. The paper also benefitted from comments by Costa Rican authorities. Special thanks to Mabel Gabriel for statistical support and Raquel Paramo and Brigitte Beyeler for editorial assistance. 
Figure 1. Labour productivity growth is slowing down convergence in GDP per capita

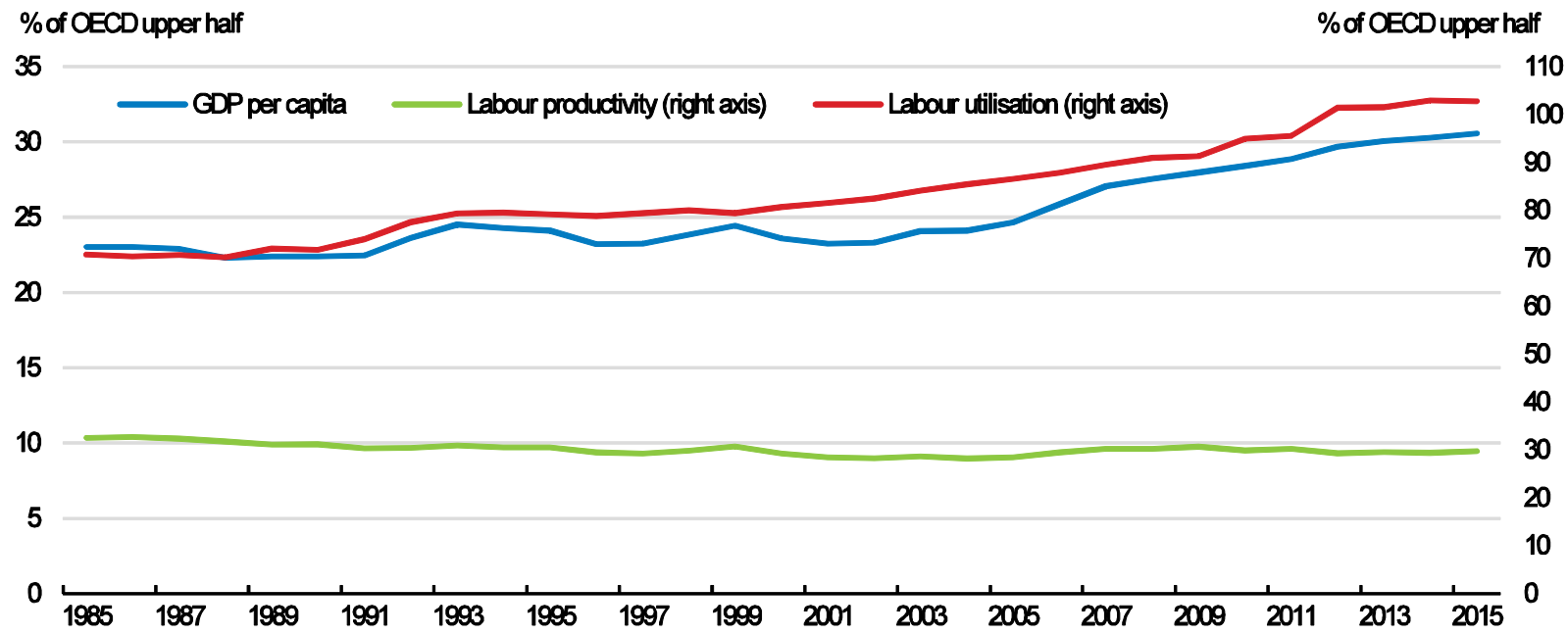

Note: OECD refers to the 17 upper half countries based on GDP per capita. GDP is expressed in 2011 PPP. Source: OECD calculations based on the Conference Board Total Economy Database.

The modest labour productivity growth Costa Rica experienced in the last 15 years is mostly attributable to sluggish multifactor productivity growth and, to a much lesser extent, low capital accumulation (Figure 2). Over time multifactor productivity growth has declined, similarly to other countries, and between early 1990s and 2014 it was overall lower than the OECD average and Chile, although higher than Mexico (Figure 3). Overall these trends, along with lower employment growth, have contributed to reduce potential output growth by nearly $5 \%$ in early 2000 s to about $4 \%$ (Figure 3), hurting growth prospects for the coming years. The slowdown in productivity has taken place despite policies promoting international markets openness and attracting foreign direct investment (FDI).

Figure 2. Low labour productivity growth is mostly attributable to sluggish multifactor productivity \% points difference with respect to the OECD average (2001-2014)

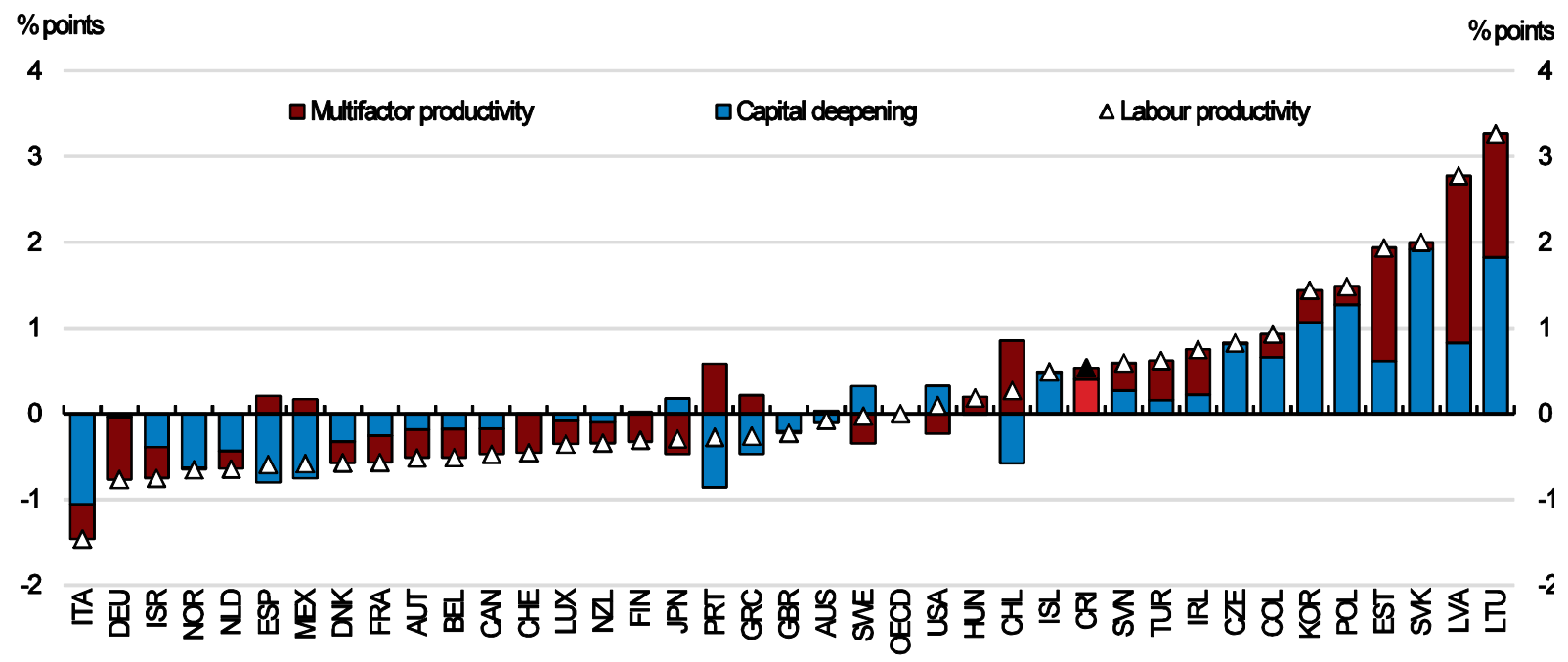

Note: The bar shows the \% points difference in countries' labour productivity growth over the 2001-2014 period with respect to the OECD average and the contribution to the difference attributable to the growth in multifactor productivity and capital deepening (i.e. capital stock over labour); growth rates are computed as logarithmic differences, which are approximately equal to percentage changes; the capital share in the production function is equal to $1 / 3$.

Source: OECD (2015h), Economic Outlook 98 Database. 
Figure 3. Potential output and productivity growth have slowed
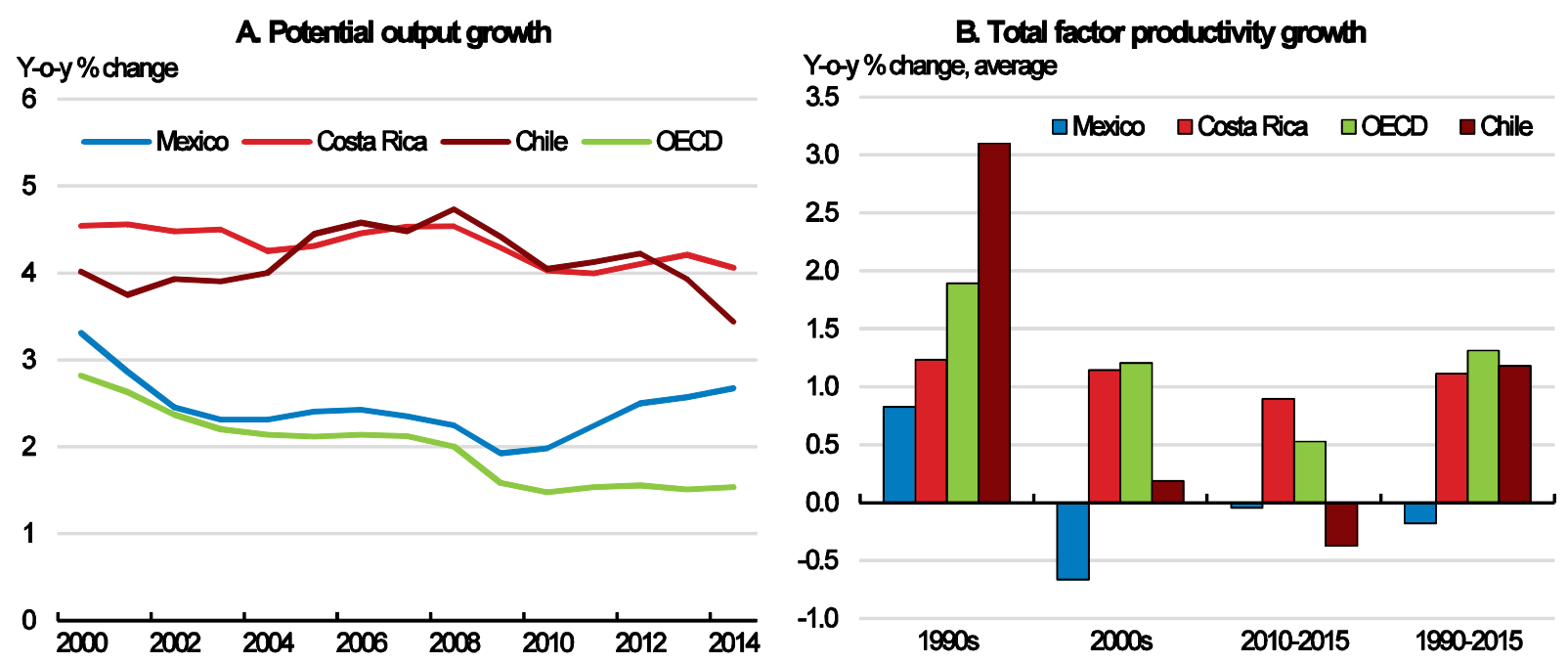

Note: Panel B: Data for Mexico is available since 1996 and for Costa Rica since 1992. OECD corresponds to the arithmetic average of the percentage annual growth of member countries whose data is available at each year.

Source: OECD (2015h), Economic Outlook 98 Database.

The continuation of the convergence process towards OECD countries' higher living standards will hinge on boosting productivity growth as further large gains from rising labour utilisation are limited. Recent OECD research underlines three key areas to boost productivity growth (OECD, 2015g): i) adopting the best available technologies at global level by the most advanced national firms; ii) creating a market environment where the most productive and innovative firms can thrive, thereby facilitating the widespread penetration of available technologies; and iii) reducing resource misallocation, particularly skill mismatches. While policies to reduce skill mismatches are analysed in the second chapter - as means to reduce poverty, inequality and labour market informality - insofar as they facilitate labour mobility and a more efficient allocation of resources they will also boost productivity. This chapter instead focuses on some of the major obstacles - low innovation and weak linkages between domestic and foreign firms, high barriers to competition and difficult access to finance, and deficient transport infrastructure - that thwart the development of domestic firms and the creation and adoption of more productive technologies.

\section{Open markets and foreign direct investment have served the country well}

Over the past three decades Costa Rica has opened up to international markets and managed to attract significant inflows of FDI. After shelving import substitution policies in the wake of the 1980s debt crisis, the country opted for an export-oriented development strategy, in which FDI and free trade zones (FTZs) played a central role, spearheading a period of gradual structural reforms. Three agencies have played a central role in the process of opening up to international market: the Ministry of Foreign Trade (COMEX), in charge of defining the country's overall FDI and international trade policies; the Coalición Costarricense de Iniciativas de Desarrollo (CINDE), responsible for promoting the country as an investment destination; and the Promotora del Comercio Exterior de Costa Rica (PROCOMER), which works on export promotion.

The FTZ regime was established in 1981 with the explicit intent of promoting exports of nontraditional products, through different tax incentives, by domestic and foreign companies. Currently, in compliance with WTO rules, the FTZ regime is open to manufacturing companies either exporting or not, whereas export requirements still apply to services companies. The FTZ regime is rule based system as the 
law clearly specifies the requirements foreign and domestic companies must meet to accede to it, in terms of, for instance, the size and geographical area of investment and sector of activity. Tax incentives currently provided include the exemption from the corporate income tax for eight years (extendable for other eight years in case additional large investments), and a reduced rate for the following four years, besides exemptions from stamp duty, property taxes, withholding tax on royalties, fees and dividends and others. The FTZ regime is geared towards increasing investment in strategic high value-added sectors such as advanced electronics and electrical components, medical devices, aerospace and offshore services (Gereffi et al. 2012).

The country has a robust legal framework protecting foreign investors' rights and the free flows of capital across borders. The Constitution clearly contains provisions enshrining the principle of nondiscrimination between nationals and foreigners, and along with secondary laws, guarantees protection against expropriation and fair compensation. There are no restrictions to transfer of foreign capital and profits. Costa Rica adhered to the OECD Declaration on International Investment and Multinational Enterprises in 2013 following the Costa Rica's OECD Investment Policy Reviews (OECD, 2013). As a signatory of the Declaration, Costa Rica is also committed to promote the OECD Guidelines for Multinational Enterprises.

As a result of these policies, Costa Rica ranks rather well in the OECD FDI Regulatory Restrictiveness Index (Figure 4). The country performs better than the average OECD country and some Latin American peers, Mexico and Chile, albeit worse than others, such as Argentina and Colombia. Costa Rica has scope to lower FDI restrictions in some sectors, especially electricity distribution, surface and maritime transport, and insurance. The country maintains exception to the national treatment for foreignowned enterprises in some sectors, such as access to land, electricity, mining or exploration of ores other than hydrocarbons and transport (OECD, 2013). 
Figure 4. Costa Rica has an attractive FDI regime but could do better
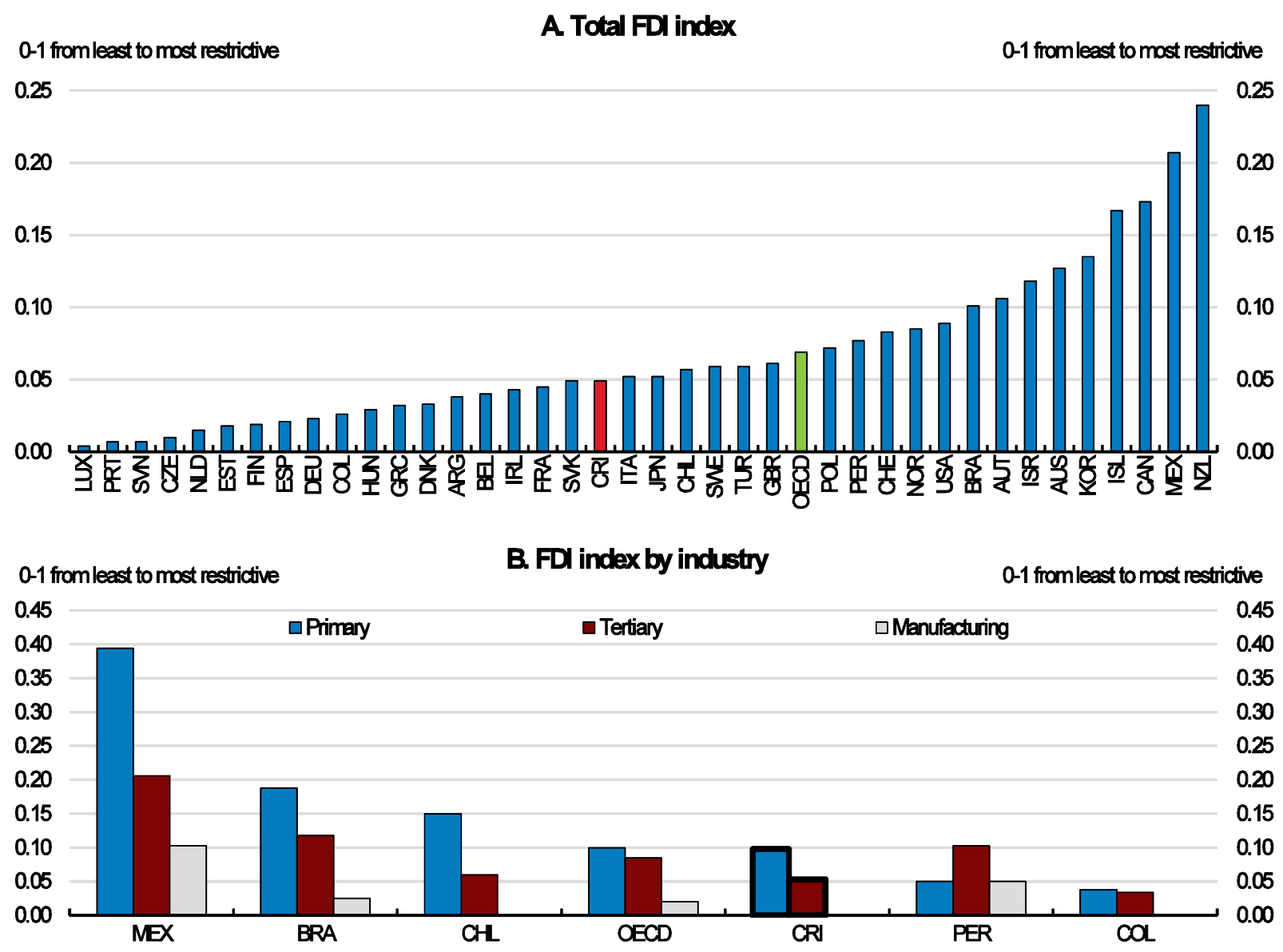

Note: Index ranges from zero (least restrictive FDI regime) to one (most restrictive FDI regime). The higher the value of the index, the more obstacles for inward FDI.

Source: OECD FDI Regulatory Restrictiveness Index Database.

FDI inflows, as a share of GDP, increased rapidly over the 1990s and 2000s, reaching a peak of $7 \%$ in 2008; their quick recovery after the sharp drop in 2009 triggered by the global economic crisis attests to the long-term attractiveness of Costa Rica as foreign investment destination (Figure 5; panel A). FDI inflows are shifting from low value added sectors - such as agro-industry, textile and apparel - to medium and high value ones - such as advanced manufacturing, life sciences and services - in addition to diversifying their origins (Figure 6). This process has contributed to increase the complexity of the economy (Figure 5; panel B). 
Figure 5. Costa Rica is an attractive FDI destination

\section{A. FDl net inflows}

\% of GDP

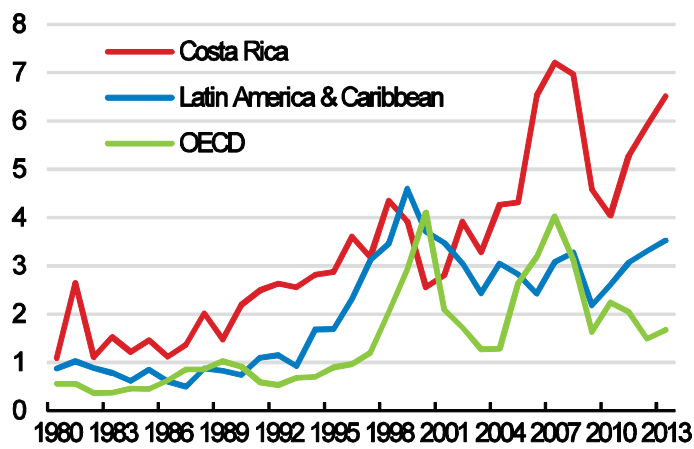

B.The economy has become more complex and diversified

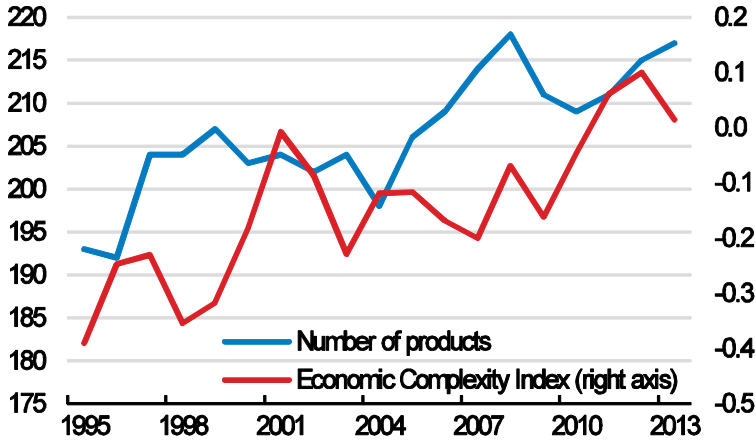

Note: Foreign direct investment is net inflows; The Economic Complexity Indicator (ECl) ranks how diversified and complex a country's export basket is. $\mathrm{ECl}$ is determined by combining in a single index a measure of a country's diversity (how many different products it can produce) and another measuring the ubiquity of those products (the number of countries able to produce those products) (Hausman, Hidalgo et al., 2014).

Source: World Bank, World Development Indicators and United Nations Conference on Trade and Development (UNCTADSTAT) and The Atlas of Economic Complexity, Center for International Development at Harvard University.

\section{Figure 6. FDI inflows have diversified}

A. By sector, average 1997-1999

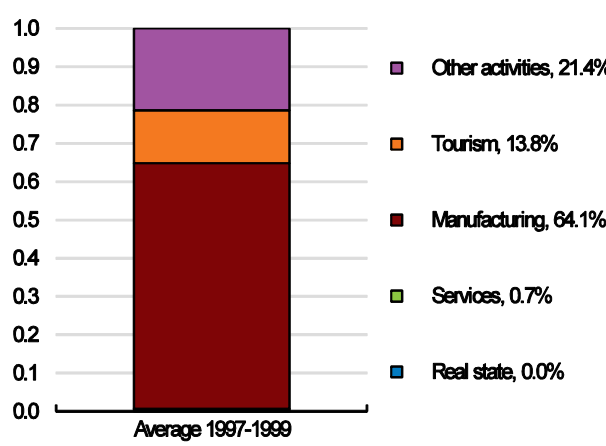

C. By country of origin, average 1997-1999

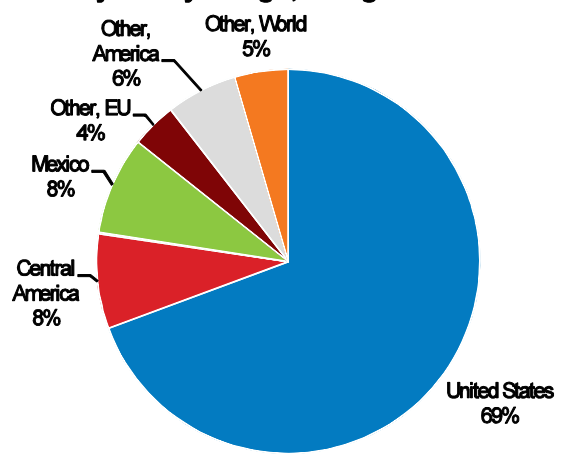

B. By sector, average 2012-2014

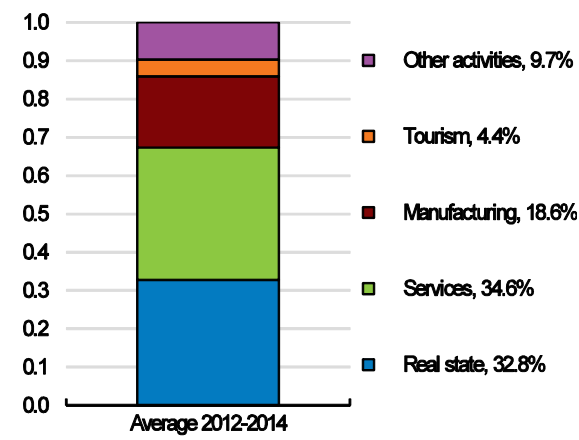

D. By country of origin, average 2012-2014

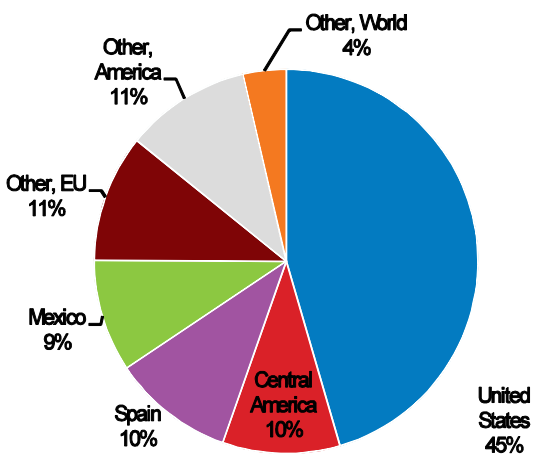

Source: Inter-institutional Foreign Direct Investment Group (Central Bank of Costa Rica, Costa Rican Investment Promotion Agency, Foreign Trade Promotion Enterprise, Ministry of Foreign Trade \& Costa Rica Tourism Board). 
FDI and free trade zones have made an important contribution to exports, increasing the value and sophistication of exported goods. Between the mid-1990s and 2014 the share in goods' exports of firms located in free trade zones (mostly foreign-owned ones) rose from about $12 \%$ to more than half the total value of goods' exports, which more than tripled over the same period (Figure 7). At the same time, the share of high technology products in total exports of manufactured products rose from about $6 \%$ - well below the OECD average - to more than $40 \%$ - higher than in any OECD country. As a consequence, Costa Rica is now well integrated into global value chains, especially in medium and high technology products (IADB, 2014). The government is seeking to deepen Costa Rica's participation in the global value added chains of four sectors, medical devices, electronics, aerospace and offshore services, by attracting foreign companies operating in these fields (Gereffi et al. 2012).

Figure 7. Free trade zones have contributed to Costa Rica's goods export performance

\section{A. Value of goods exports}

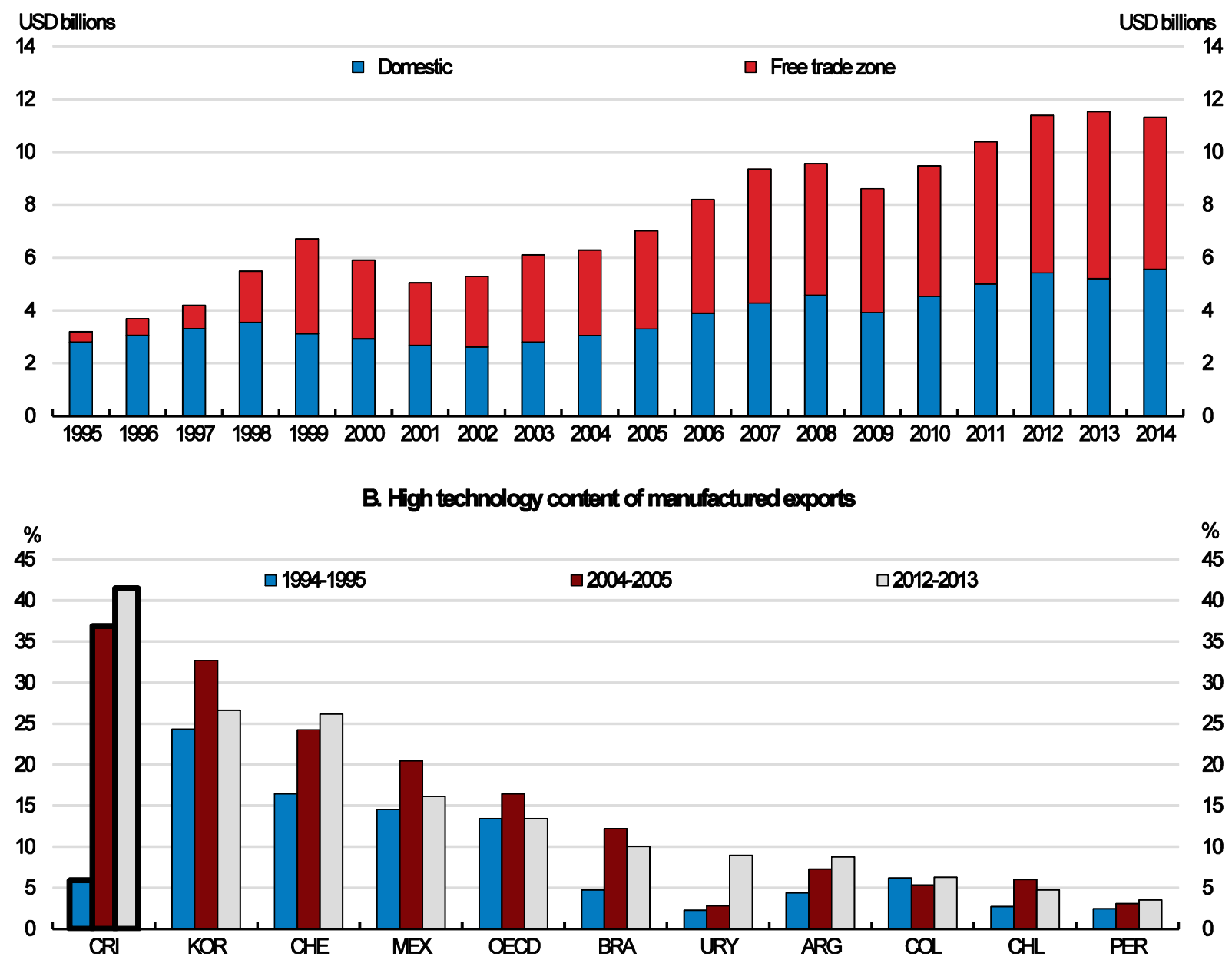

Note: High-technology exports are products with high R\&D intensity, such as in aerospace, computers, pharmaceuticals, scientific instruments, and electrical machinery.

Source: COMEX and World Bank World Development Indicators. 


\section{Raising productivity will require a whole of government approach}

Improving productivity will require actions across several policy areas such as education and skills, innovation, competition and infrastructure. Co-ordinating initiatives across all these policy areas and breaking policy silos will be crucial to managing trade-offs and building complementarities. The government is aware of this challenge and it has established the Presidential Council on Competitiveness and Innovation (CPCI), to co-ordinate policies. It is composed of three sub-councils - Council on Competitiveness, Council on Innovation and Human Talent, and Alliance for Employment and Development - with representatives from ministries and the private sector and it has the support of a small technical unit.

The establishment of the CPCI is a good development and is consistent with similar initiatives in OECD countries, such as Australia, Chile, Mexico and New Zealand, which have created productivity commissions. Such commissions can play a useful role by providing open and impartial advice to the government and parliament based on sound data and research (Banks, 2015). To become more effective in identifying obstacles to productivity growth and propose policy options to overcome them, CPCI should be streamlined, by merging the three sub-councils into one, and assume a more strategic role. The technical unit should be strengthened and made more independent from the executive by staffing it with experts in the subject areas under the remit of the CPCI coming from the academia, private sector and think thanks. This reformed technical unit would be better able to supply the council with the necessary inputs to provide evidence-based policy advice. The council could be tasked to prepare and update at regular intervals long term strategic plans to be submitted to the government and parliament for discussions and approval. Overall, this institutional setup would result in a more coherent policy framework and time-consistent policies, and raise the quality of public debates on productivity issues, among which innovation, competition and infrastructure.

Other efforts to improve the coordination and implementation of policies to boost productivity are also underway. These include a draft law to create an agency (Agencia Costarricense de Fomento Productivo, Innovación y Valor Agregado, FOMPRODUCE) with a public-private governance structure, which will centralise funds and functions currently dispersed across several agencies, to facilitate the establishment of businesses and promote innovation. This initiative is welcome as it will reduce institutional and policy fragmentation. The government should press for the swiftly approval and establishment of FOMPRODUCE.

\section{Enhancing links between the foreign and domestic firms and encouraging innovation}

Despite the large FDI inflows, benefits in terms of technological and knowledge spillovers have so far been limited. Foreign affiliates tend limit their purchases from local suppliers to unsophisticated products and services, such as packaging materials, office supplies, security and food. As a result, large labour productivity differences between firms in and outside the free trade zone regime persist (Figure 8). Also, wages differences between foreign and domestic companies are also large (see Chapter 1), hampering labour mobility and thus the transfers of technologies and know-how. While the investment promotion agency (CINDE) has shown to be a small but effective institution in attracting FDI it has played only a minor role in promoting linkages between foreign and domestic companies. The export promotion agency (PROCOMER) manages programmes promoting linkages between foreign and local suppliers, but actual linkages so far have been below expectations as foreign companies use superior technologies and produce higher quality products than domestic companies.

Strengthening linkages between domestic and foreign firms will hinge on improving the technology and quality of products of domestic companies. In this respect, R\&D activities will be paramount as not only they stimulate innovation but also favour technology transfers (Griffith et al., 2004; Adalet McGowan 
et al., 2015). In Costa Rica, gross expenditure on R\&D and the numbers of employees involved in R\&D activities are significantly lower than in most OECD countries, although not dissimilar from other Latin American countries such Argentina, Chile, Colombia and Mexico (Figure 9). Costa Rica's gross expenditure on R\&D was only $0.5 \%$ of GDP in $2011-0.6 \%$ in 2012 and 2013, according to national source (MICITT, 2015). Businesses' R\&D spending is exceedingly low (Figure 9) and mostly performed by large firms and foreign affiliates in free trade zones. Overall, this results in a number of patent applications per thousands of people that is considerably lower than the OECD average, albeit not dissimilar from peer Latin America countries (Figure 10).

Figure 8. Labour productivity differences between firms in and outside free trade zone are large

2011-2012 average

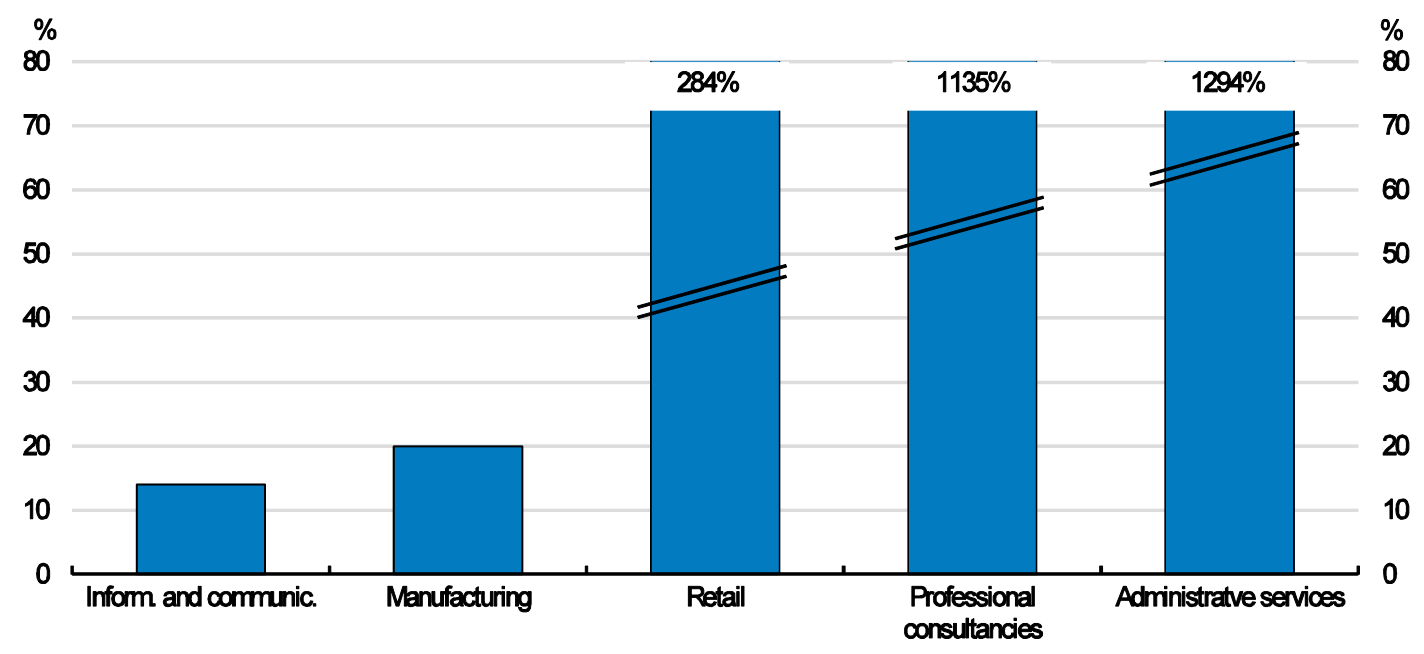

Note: The bars show the percentage difference in average labour productivity (expressed as value added per worker) of firms in and outside free trade zones; values refer to the average of 2011 and 2012 (the latest available years); some sectors are not reported because of no or too low number of firms operating in free trade zones.

Source: OECD calculations and Central Bank of Costa Rica data.

The share of R\&D performed in higher education is still limited compared to other OECD countries. In many OECD countries higher education has replaced public research institutes as the main performer of publicly-funded research (OECD, 2015f). An important cause of this change is the universities' teaching role and the set of skills and research capacity universities nurture. Shifting R\&D activities to universities would be a conduit to stronger linkages with local innovative companies (and foreign affiliates) and enhance the career prospects for graduates of technical and scientific disciplines, thus ultimately increasing their number and reducing skill mismatches in the labour market. Also, more intensive collaboration between universities and local firms could facilitate the diffusion of innovative foreign technologies in the business sector through universities international contacts and research programmes (McGowan et al., 2015; OECD, 2015g;). To take full advantage of the knowledge being generated in universities it will be important to consolidate and scale up the Ministry of Science, Technology and Telecommunication's current efforts to work collaboratively with universities with the aim of connecting researchers with private sector firms and fund research-based innovation projects.

The current ways to finance public $R \& D$ spending seems to be well suited to increase the share of public R\&D spending in higher education as it relies to a large extent on competitive grants and not on R\&D tax incentives (Figure 11). Given the small size of local companies, R\&D tax incentives, such tax credits, would be an ineffective way to boost innovation in Costa Rica. Competitive contracts, grants and awards are more effective instruments to increase R\&D activities in small and young firms (OECD, 2015g). 
Figure 9. Research and development (R\&D) activities are low

\section{A Gross expenditure in R\&D}

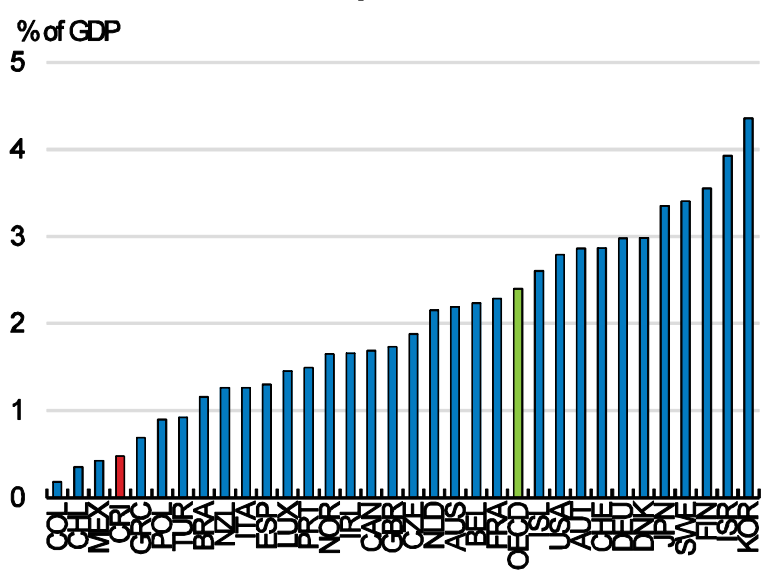

\section{B. Researchers}

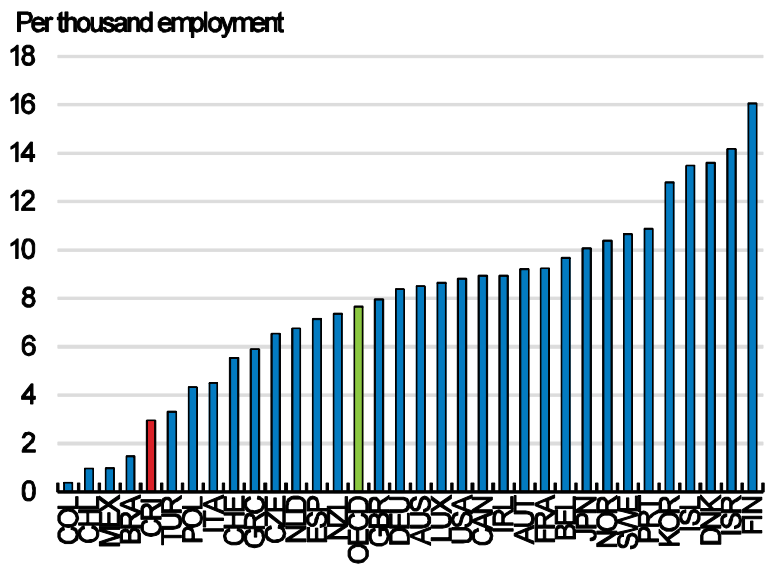

C. The public sector accounts a large share of R\&D spending

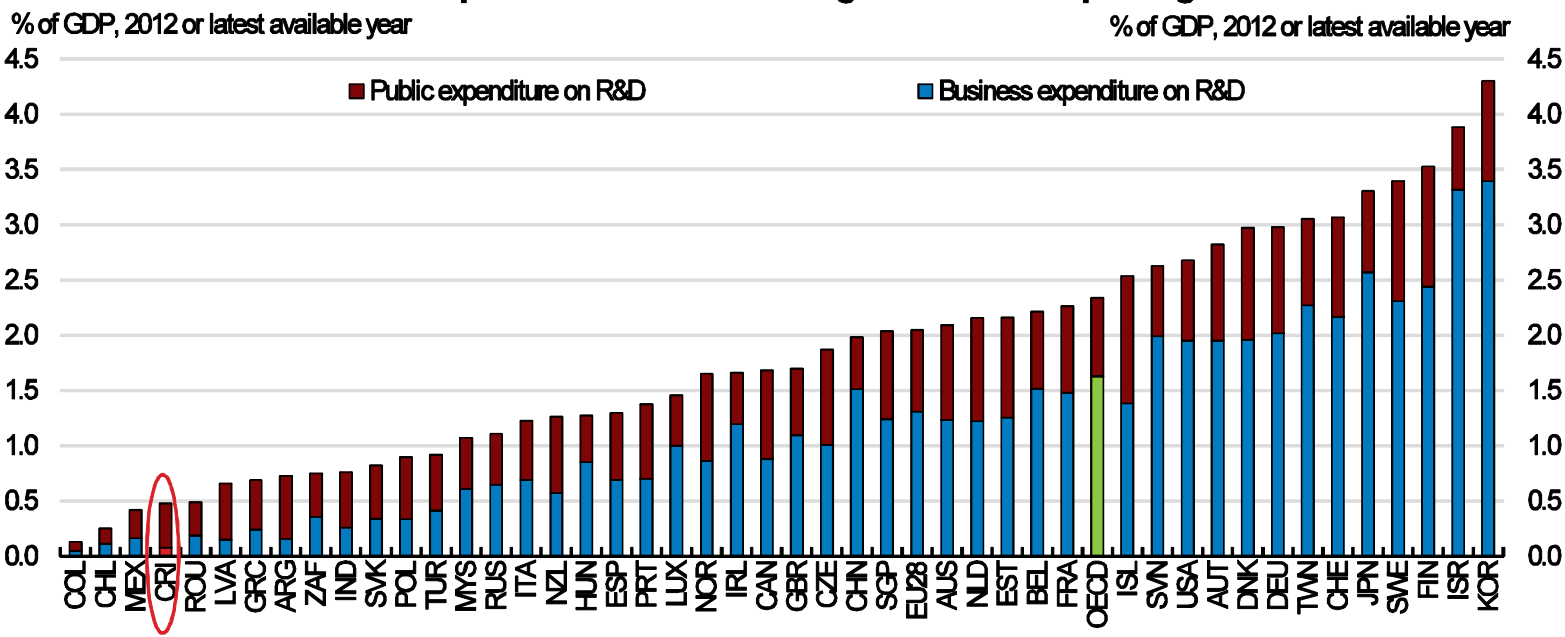

D. Higher education contributes less to public R\&D expenditure than in other countries

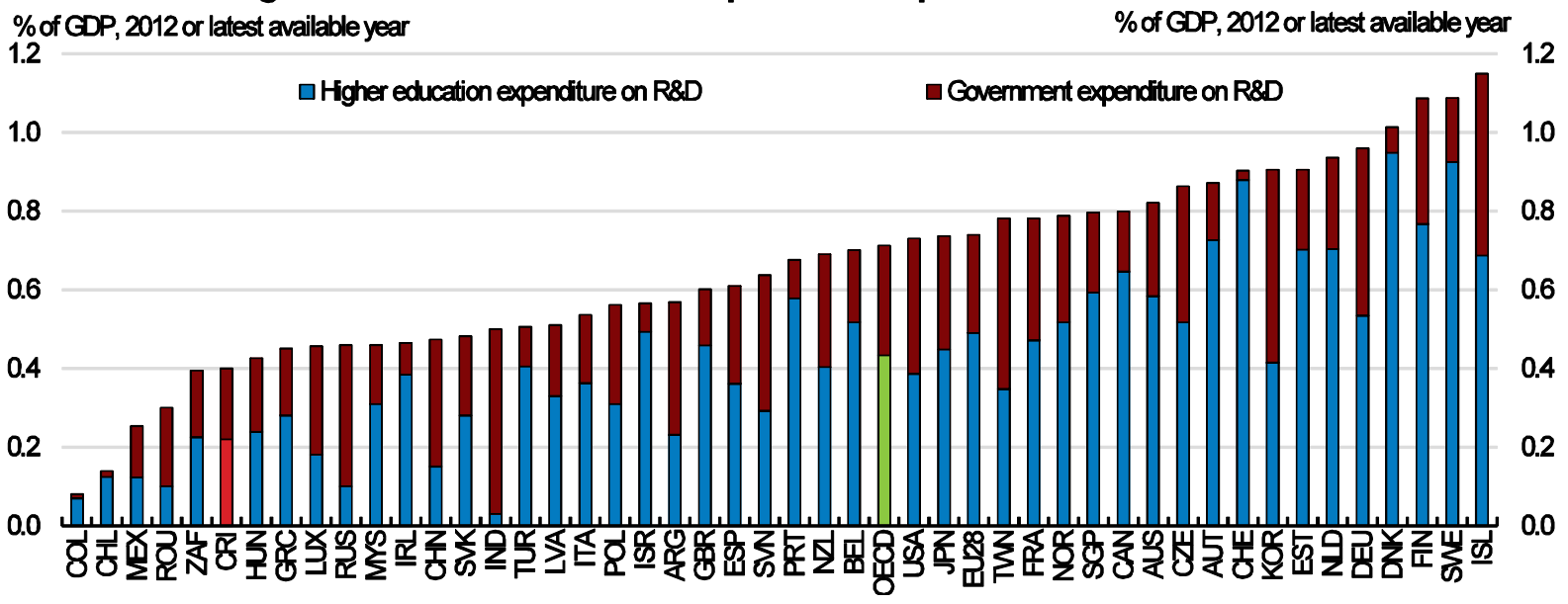

Note: Panel A: Gross expenditure on R\&D as a percentage of GDP for 2013 or latest year available. Panel B: Researchers per thousand employment for 2013 or latest year available. Panel C: Total R\&D expenditure (public and business) as a percentage of GDP, 2012 or latest available year. Panel D: Public R\&D expenditure by type of research system. HERD and GOVERD, as a percentage of GDP, 2012.

Source: OECD, Main Science and Technology Outlook 2014; Eurostat; UNESCO Institute for Statistics (UIS), June 2014. 
Figure 10. Costa Rica has low patent applications compared with OECD countries

2013

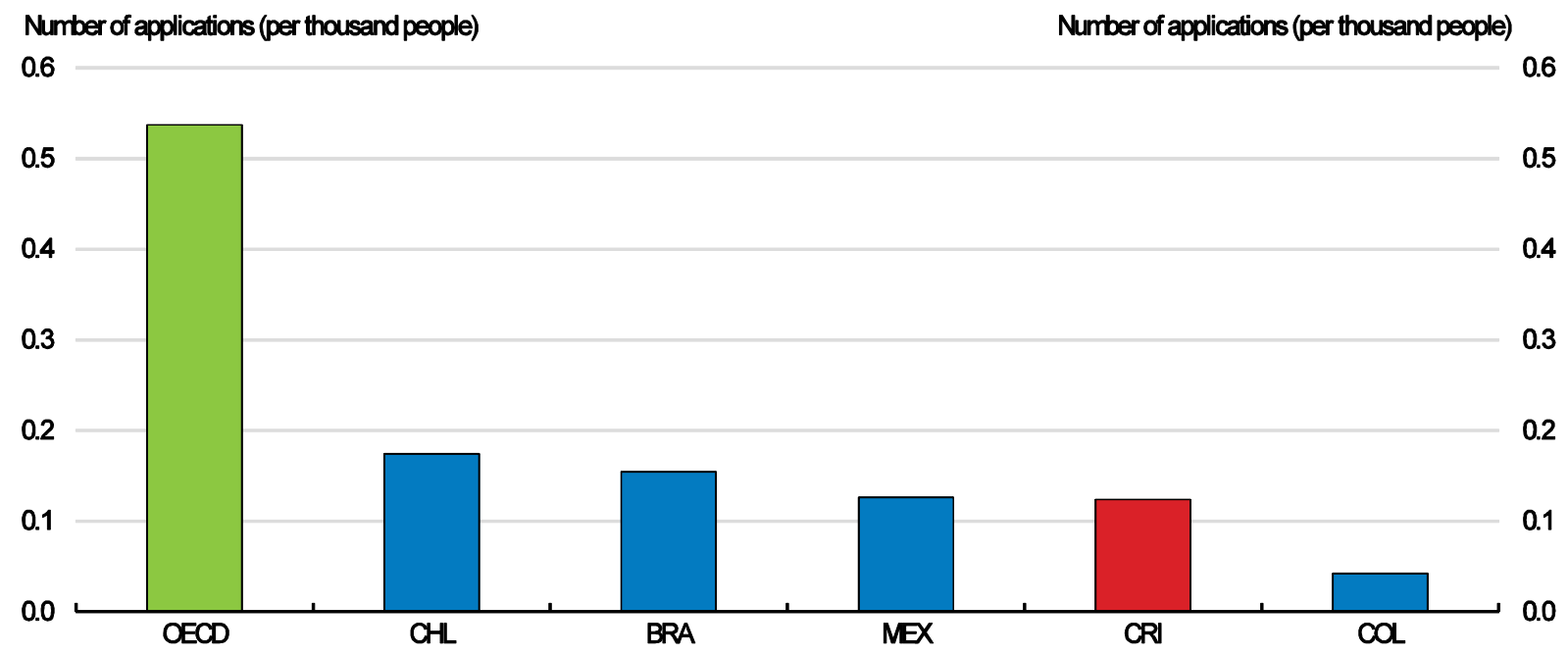

Note: Patent applications refer to residents and non residents. Source: World Bank, World Development Indicators.

Figure 11 Most relevant instruments of public funding of business R\&D 2014

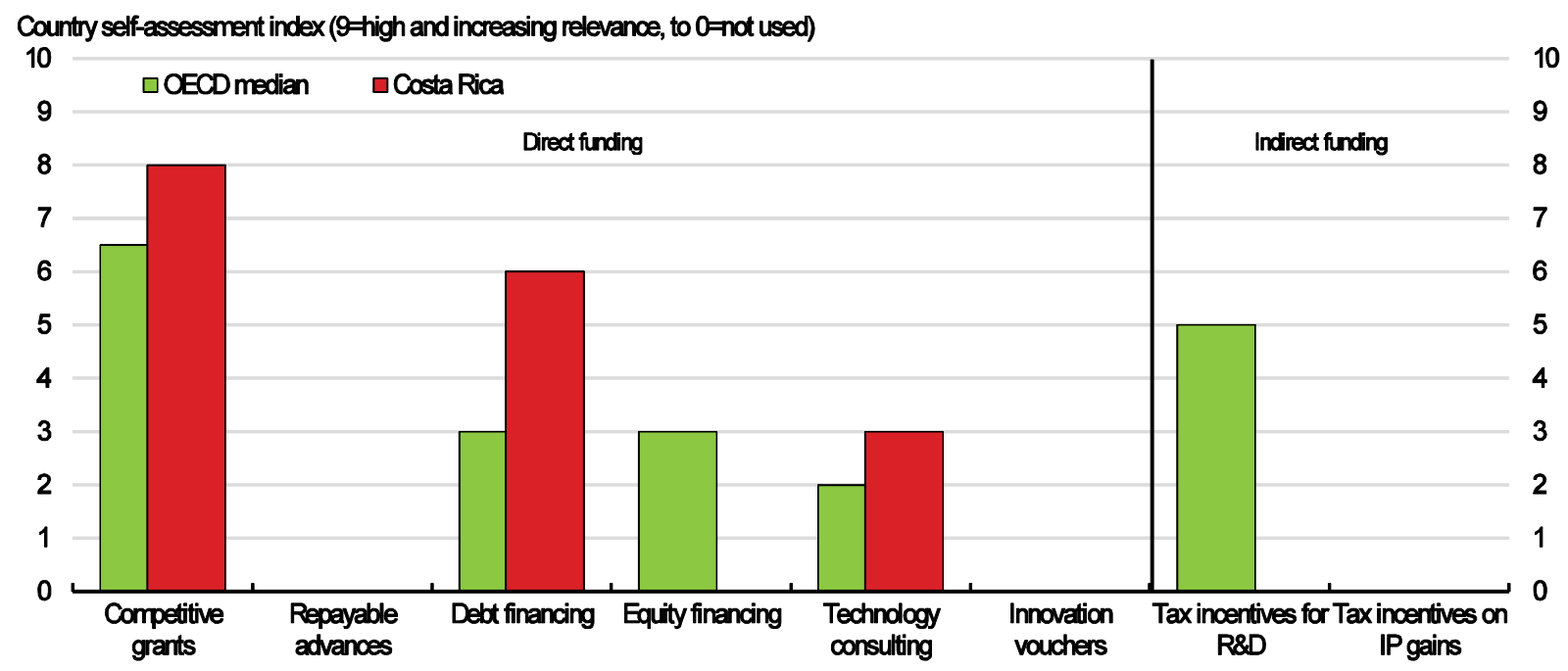

Source: OECD, based on country responses to the OECD Science, Technology and Industry Outlook policy questionnaire 2014.

The legal framework for intellectual property rights is in compliance with ratified international treaties and trade-related commitments (OECD, 2013; OECD, 2015d) but enforcement is weak. Costa Rica's intellectual property rights protection is part of the strategy to attract foreign investors but enforcement still presents problems, especially in terms of copyright piracy and trademark counterfeiting. In 2011 with the support of the World Intellectual Property Organisation, the country developed a national intellectual property strategy. On that basis, Costa Rica is amending the patent law and has reinforced prosecution of intellectual property rights violations in the attempt to improve enforcement (OECD, 2014d). These efforts should be continued and coupled with initiatives to strengthen awareness and the effective use of IPRs in universities and local firms. 


\section{Improving coordination between innovation and foreign-domestic linkages programmes}

The government has adopted policies to promote businesses' innovation and linkages between foreign and domestic companies. Two prominent examples are the funding programmes PROPYME (Programa de Fortalecimiento para la Innovación y Desarrollo de las PYMES) - managed by the Ministry of ScienceTechnology and Communications to promote innovation and technological development in SMEs through grants - and CRP (Costa Rica Provee) - managed by PROCOMER to improve linkages between foreign and domestic companies by matching suppliers with buyers. Policy evaluation suggests that these programmes improve beneficiaries' performance metrics, such as employment, profitability and exports, with stronger effects for firms enrolled in both programmes (Monge Gonzáles et al., 2010; Monge Gonzáles and Rodriguez-Álvarez, 2013).

Given these positive results of PROPYME and CRP, the government should scale them up, and improve their coordination. The effort the Ministry of Science, Technology and Telecommunications to increase funding to this sort of programmes through IADB loans is therefore welcome. As the outcomes of programmes and activities aiming at boosting innovation in local companies and deepening their links with foreign affiliates are tightly connected, establishing a one-stop agency is likely to improve their effectiveness. In this area, the establishment of the agency FOMPRODUCE, as envisaged by a draft law proposed by the government (as described above), to concentrate funds and responsibilities concerning firms' innovation and development in a single entity, is an initiative going in the right direction. However, programmes to strengthen innovation and links with foreign affiliates will need to be carefully evaluated and the government should commission policy evaluations on a regular basis to assess their cost effectiveness and inform future policy changes. In addition, CINDE and PROCOMER should reinforce their companies' monitoring capabilities and post-establishment services so as to further facilitate links of foreign affiliates with the local economy.

\section{Improving the competition regime and access to finance}

\section{Restrictions to product market competition are significant}

Strengthening competitive pressures in product markets can boost living standards and welfare, by increasing productivity and product quality and lowering product prices (e.g. Bouis and Duval, 2011; Bourlès et al., 2010; Conway et al., 2006; Koske et al., 2015). Many OECD countries have removed regulations restricting competition in product markets by, for instance, reducing state involvement in business sectors and making it easier for entrepreneurs to create firms.

According to OECD's Product Market Regulation (PMR) indicator, regulation in Costa Rican product markets is stringent. Among OECD countries, only Turkey has a higher level of the PMR index than Costa Rica; Latin American peers, such as Chile, Mexico and Colombia, perform better than Costa Rica (Figure 12). The sub-indicators of the PMR reveal that state controls and barriers to entrepreneurship are especially high (Figure 13). State controls are particularly restrictive because of large government involvement in network sectors, poor governance of state owned enterprises and extensive price controls. Barriers to entrepreneurship are an obstacle to competition because of the license and permits system, administrative burdens for sole proprietors of firms, antitrust exemptions and barriers in network sectors.

Costa Rica fares better in terms of barriers to trade and investment due to the transparency and accountability of its trade and investment framework. Despite these progresses, Costa Rica's tariffs are still $20 \%$ higher than the OECD average (65\% higher for consumer goods and almost $15 \%$ higher for raw materials). The top 20 highest tariffs apply to some agricultural products, such as meat, dairy products, sugar and rice (see Chapter 1) (OECD, 2015d). 
Figure 12. There is scope to ease regulation in product markets

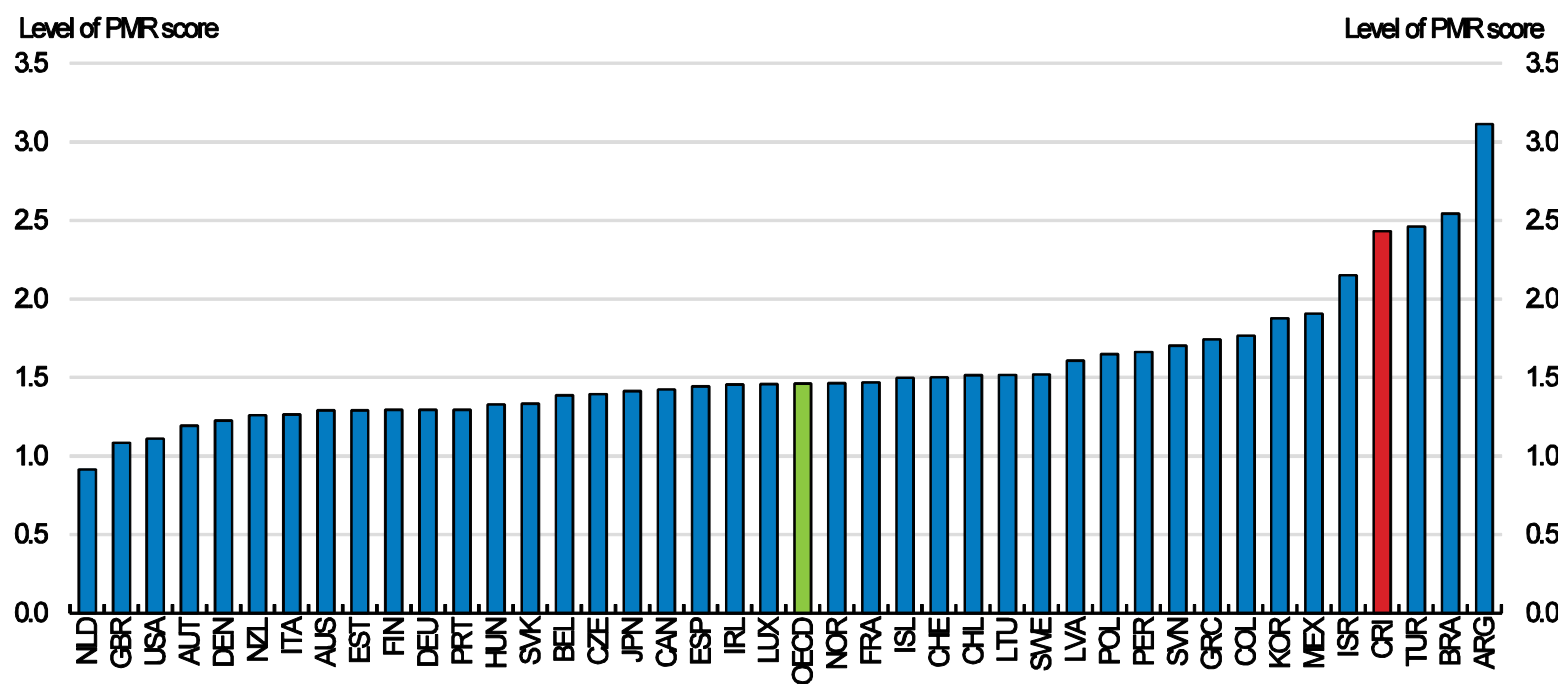

Note: OECD is a simple average of OECD countries, 2013 data. USA latest data is 2008.

Source: OECD Product Market Regulation Database, for OECD Countries and Brazil; OECD-World Bank Group Product Market Regulation Database, for Colombia, Peru and Costa Rica.

The 1949 Costa Rica Constitution contains provisions to support competition. The Constitutions mentions free trade, agriculture and business as fundamental rights of people. However, for a long time these provisions were interpreted mainly as against private monopolies and before the 1980s were construed to allow for import protection policies, price controls, restrictions to market entry and state ownership in key sectors such as electricity, telecommunications, transport infrastructure, banking and insurance.

Current competition policy dates back to the 1990s, when the competition and consumer protection law was approved as requirement of the free trade agreement with Mexico signed in 1994. Another important moment in the process of opening up the economy to competition was the signing of the Central American-Dominican Republic Free Trade Agreement with the United States (CAFTA-DR), which required the abrogation of legal monopolies in the telecommunications and insurance sectors, which were liberalised in 2010 and 2011. 
Figure 13. State controls and barriers to entrepreneurship restrict competition

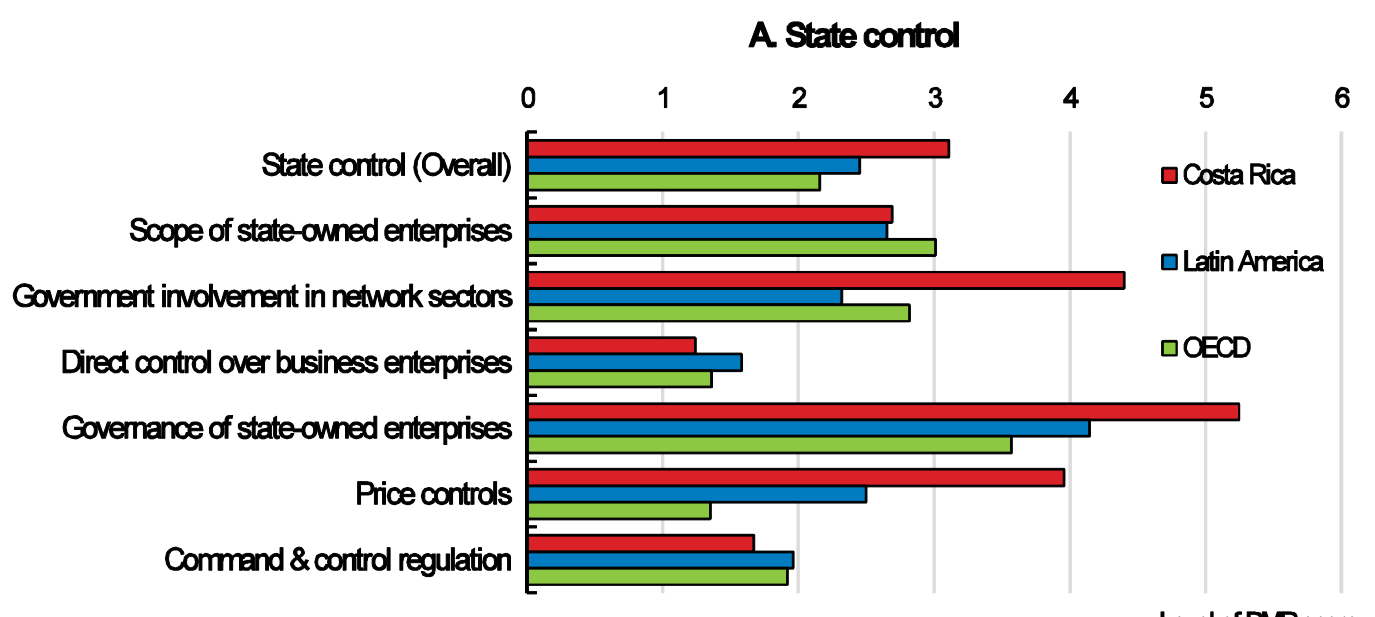

\section{B. Barriers to entrepreneurship}

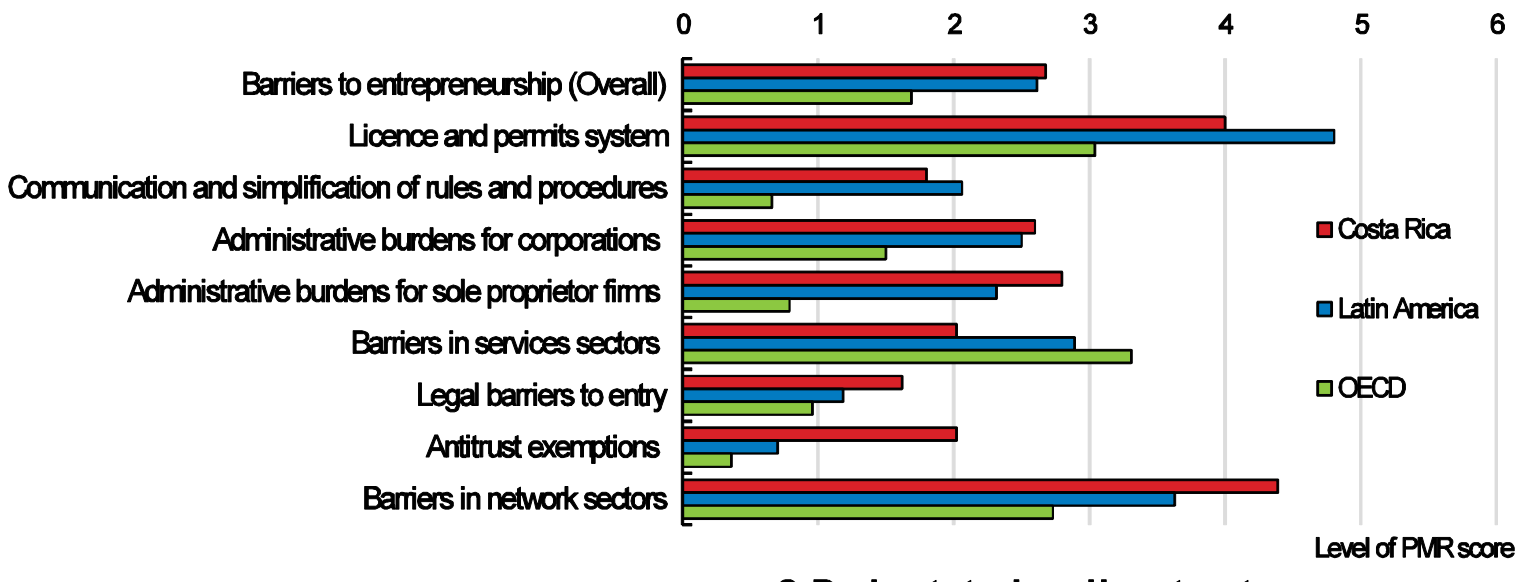

C. Barriers to trade and investment

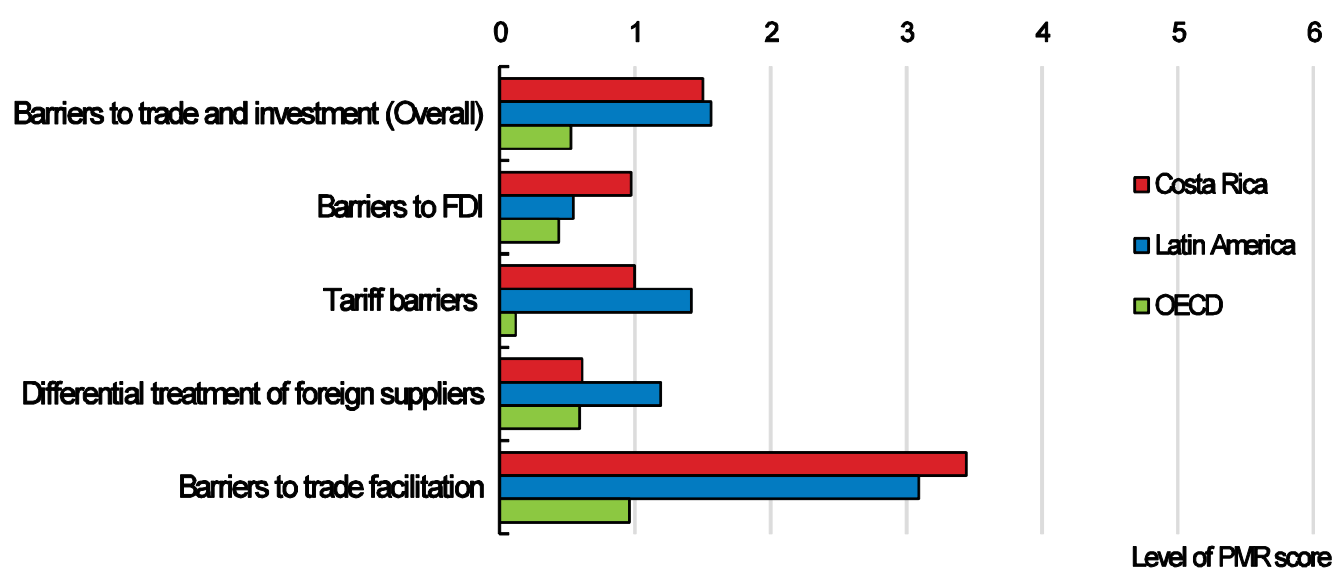

Note: Simple average of OECD and 12 Latin America countries, 2013 data. USA latest data is 2008.

Source: Source: OECD Product Market Regulation Database, for OECD Countries and Brazil; OECD-World Bank Group Product Market Regulation Database, for Colombia, Peru and Costa Rica. 
The key agencies shaping the Costa Rican competition regime are:

- The Competition Commission (Comisión para Promover la Competencia, COPROCOM). Established in 1998, COPROCOM enjoys a degree of decisional autonomy; it is an agency of the Ministry of Economy, Industry and Commerce (MEIC) and as such does not have administrative and budgetary independence.

- The Public Services Regulatory Authority (Autoridad Reguladora de las Servicio Públicos, ARESEP). Established in 1996, its responsibilities involve regulating and setting tariffs for public services, namely water and waste, electricity, buses and taxis, fuels (petroleum and its derivatives), airports, railways and ports. The law clearly mandates that services in these sectors can only be provided upon obtaining a state concession. ARESEP is an independent institution as it was created as a decentralised agency; it has its own budget, partly funded with charges on regulated companies.

- The Superintendence for Telecommunications (Superintendencia de Telecomunicaciones, SUTEL). Created in 2008 with the liberalisation of the telecommunications sector, it is part of ARESEP; SUTEL has the double role of regulator and competition agency for the telecommunications sector; it is a decentralised agency with its own budget partly funded with charges on companies.

\section{The competition regime needs to be strengthened}

Markedly reducing barriers to entrepreneurship will improve the business environment and enhance competitive pressures, in addition to reducing labour market informality (as analysed in Chapter 1). More specifically, among barriers hampering entrepreneurship, the license and permits system and administrative burdens for sole proprietor firms are significantly higher than the OECD average. OECD best practices indicate that establishing one-stop agencies and adopting the "silence is consent" rule can significantly lower these barriers. Over the past five years, most OECD countries have made progresses in this area by, for instance, modernising license and permits systems, streamlining administrative procedures for startups, simplifying rules and procedures and improving access to information about regulation (Koske et al., 2015). Costa Rica has ample scope for making similar improvements and move towards OECD standards.

Eliminating anti-trust exemptions, without creating private monopolies, is key to exposing a larger share of the economy to competitive forces and improving welfare. As underlined in previous OECD reports (OECD 2014a, 2015b), best international practices among OECD countries have moved towards repealing anti-trust exemptions. Currently, the sectors exempt from the competition law include all public services requiring state concessions by law, i.e. all services under the purview of ARESEP, with the exception of airports. In many of these sectors competitive pressures among market players are feeble or non-existent. Private participation is admitted in only some of them, such as electricity generation, seaports services, buses and taxis, and prohibited in others, such as railways and water.

The electricity sector is dominated by state-owned enterprises and private-sector participation is limited by statutory restrictions. In 2014, the Instituto Costarricense de Electricidad (ICE) generated about $71 \%$ of the total electricity supply, six percentage points lower than in 2004, with municipalities and cooperatives and private companies accounting for the remaining share. ICE also provides all transmission service in the country and is responsible for about $40 \%$ of electricity distribution. Its subsidiary Compañía Nacional de Fuerza y Luz (CNFL) distributes around $40 \%$ of generated electricity while municipal companies and co-operatives cover the rest of power distribution in rural area. ICE and all other electricity distribution companies provide their services under monopolistic conditions as all have exclusive marketallocation areas. Private companies are allowed only in the electricity generation and can sell their 
electricity to ICE only. Private-sector generators compete for the market rather than in the market, because to enter the market they must first win ICE's tendering contracts, which also specify the quantity of electricity ICE will purchase. Recent legal changes have increased the share of allowed private-sector electricity generation from 15 to $30 \%$. Allowing private generators to compete in the market, and not only for the market, and a stricter functional separation between electricity generation and distribution by stateowned entities would yield larger benefits from increased private sector participation.

Two state-owned enterprises - INCOP and JAPDEVA - dominate maritime transport as they have the exclusive right to manage all ports on the east and west coasts respectively. Both have the double role of port authorities and port operators. Given the importance of maritime transport for Costa Rica as means to connect with international markets, the country would benefit from adopting the management concept of landlord port, whereby port authorities owns and manages the land and basic ports' infrastructure that are then rented or leased to different private port operators on a competitive basis. Similar changes in Mexico and other countries have resulted in significant improvements in the productivity of ports and reductions in cargo handling charges (Estache et al., 2004; Cheon et al., 2010).

Other important markets outside the scope of the competition laws include: imports, refinery and distribution of wholesale petroleum and its derivatives, for which the state owned Costa Rican Petroleum Refinery (RECOPE) has a legal monopoly; the manufacture of alcohol for beverages, for which the National Liquor Factory (FANAL) has a legal monopoly; the production and commercialisation of sugar and rice, which are subject to sector specific laws and are regulated by two cooperatives - the Agriculture League of Sugarcane Industry (LAICA) and National Rice Corporation (CONARROZ); professional services, following a 1999 pronouncement of the Constitutional Court (OECD, 2014a).

Lifting restrictions to competition would generate large benefits for the society as a whole. The recent experience of the telecommunications sector points in this direction and could serve as a template for other sectors. To date, four private companies, in addition to the former state monopolist (ICE), operate in the mobile-phone market and more than ten companies are active in each of the fixed telephony and internetaccess markets (SUTEL, 2015). This drastic increase in competition resulted in a large expansion of telecommunications services and lower prices (Figure 14). In addition, between 2010 and 2014, employment in the telecommunications sector increased by $40 \%$, against $10 \%$ for the whole economy.

Figure 14. The telecommunications sector has expanded since opening up to competition
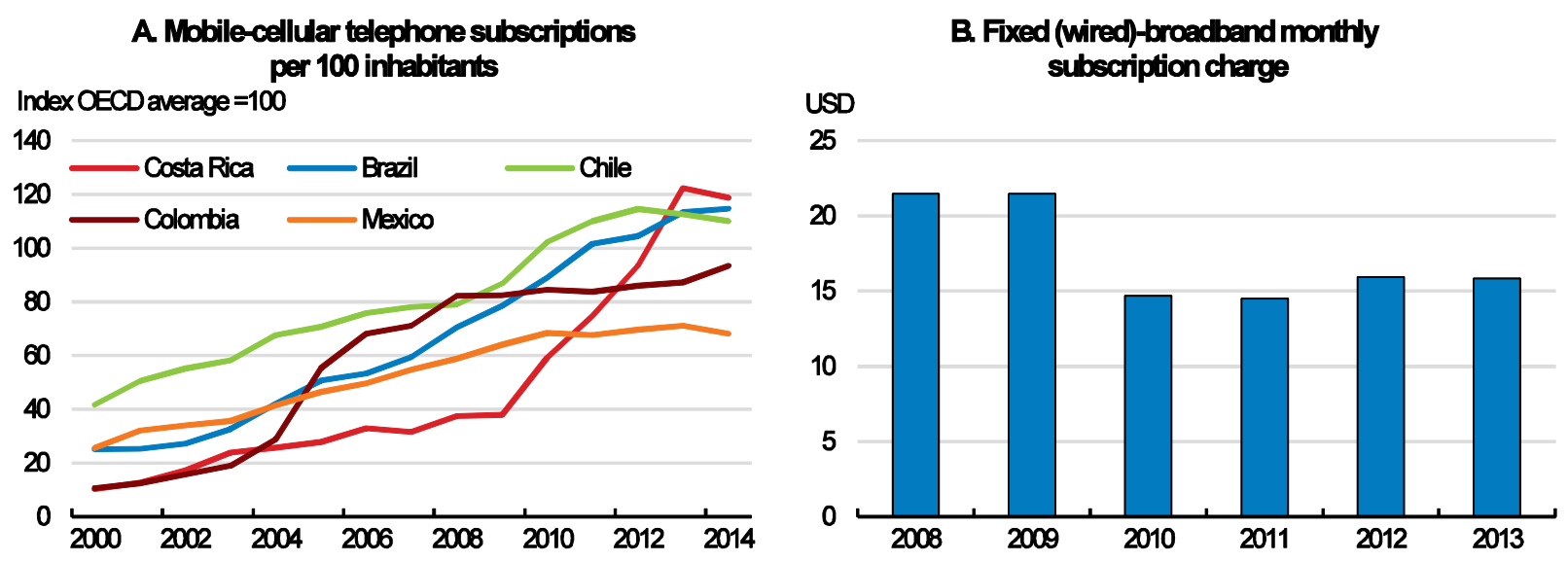

Source: International Telecommunications Union, World Telecommunication/ICT Indicators Database 2015. 
The government should also grant COPROCOM more decisional, administrative and budgetary independence in addition to enhancing its financial resources. Being an "órgano desconcentrado" ("deconcentrated" body) of the MEIC, COPROCOM already enjoys some decisional autonomy in conducting investigation and decisions to impose fines. However, unlike SUTEL and ARESEP COPROCOM does not have administrative independence and a separate budget from the ministry to which it is attached. The resignation of three commissioners of COPROCOM in mid-2015 following a restructuring of the commission led by MEIC (Arias, 2015) attests to the inadequacy of the present institutional set up that weakens effective implementation of the competition law.

COPROCOM should also be granted the power to conduct market studies. Market studies consist of research projects aimed at improving authorities' understanding of how sectors and markets work. Market studies may conclude that the market is working satisfactorily or highlight problems, which can then be used as an input in specific investigations on anticompetitive practices (OECD, 2015b). COPROCOM's powers should also be enhanced by establishing a leniency programme for whistle-blowers, which currently does not exist, increasing fines and sanctions, as their current levels do not appear to have deterrent effects, consider establishing criminal offences for the most serious cases of misconduct and banning the possibility of notifying mergers after they have taken place, as un-doing those considered illegal could be difficult or impossible (OECD, 2014a).

COPROCOM financial and human resources should be increased. Nearly all its budget is devoted to wages and salaries (Figure 15). The budget and resources of COPROCOM compare unfavourably even with those of SUTEL and ARESEP. Nevertheless, COPROCOM has shown a strong commitment to enforce competition laws by sanctioning, between 1995 and 2014, 25 absolute and relative monopolistic practices among different firms, including telecom operators, pension funds, container carriers, pharmacies and car dealers (OECD, 2014a).

Figure 15. COPROM has a low budget compared with other competition authorities in the region 2012

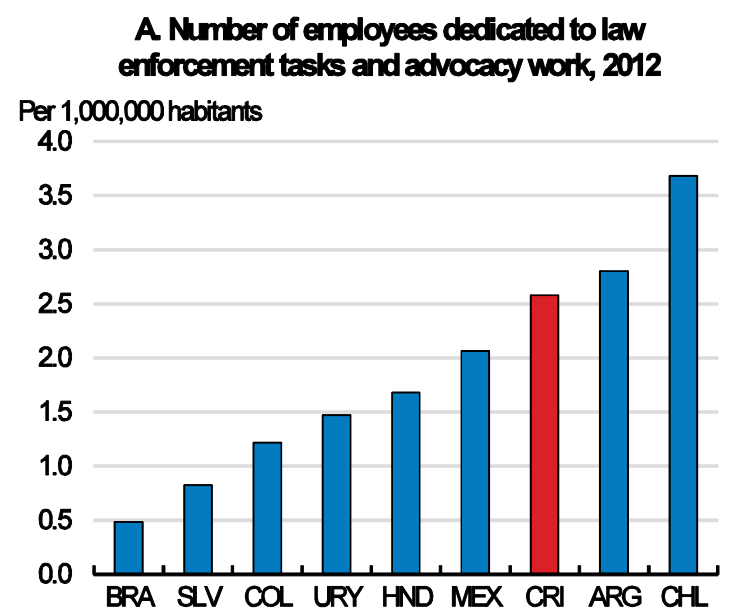

B. Agency budget, 2012

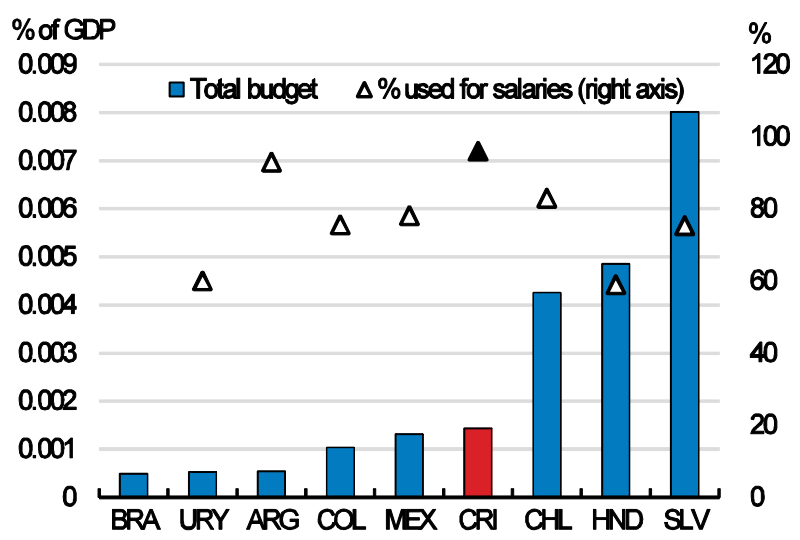

Note: Chile includes the sum of the Tribunal de Defensa de la Libre Competencia and Fiscalía Nacional Económica. Budget data for Brazil is provided in Brazil Real and converted to USD using 2012 average exchange rate.

Source: Centro Regional de Competencia para América Latina and World Bank World Development Indicators. 
The way tariffs of regulated services - energy, transport and water - are set by ARESEP limits competitive pressures and results in fast-rising costs for users. The law instituting and regulating ARESEP clearly mandates that tariffs be based on the (reasonable) costs incurred by service providers and to ensure their financial viability (i.e. cost-based pricing or rate-of-return regulation), which guarantee a certain rate of return on the capital invested. While this type of price regulation ensures tariffs are set at cost recovery levels, it provides no incentives for productivity improvements because cost increases can be easily passed onto consumers. Between 2006 and 2014, tariffs of regulated services rose more than any other business cost (CAATEC, 2014). Because of past price increases, in 2013 electricity tariffs were higher than the OECD average - especially for industry (Figure 16).

Figure 16. Industry electricity tariffs are higher than in most OECD countries

\section{A Industry electricity prices}

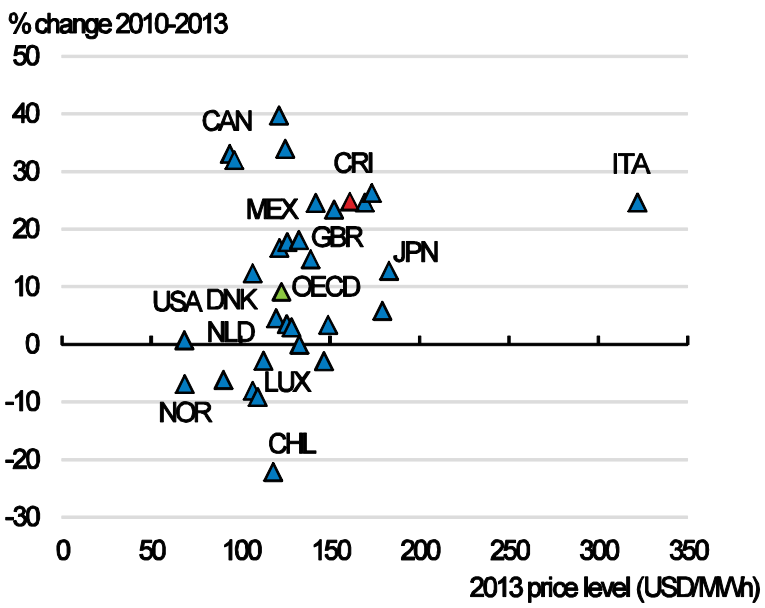

B. Households electricity prices

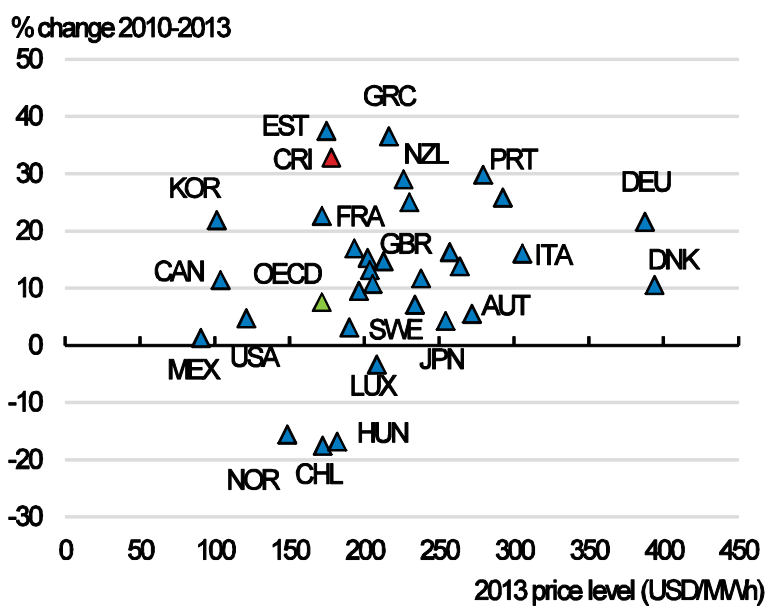

Note: Costa Rica data comes from CEPAL and refers to the average price.

Source: IEA, Energy Prices and Taxes Database; CEPAL, Centroamérica: Estadísticas del Subsector Eléctrico, 2013.

Setting tariffs for public service in a way to encourage productivity improvements and the adoption of cost saving technologies would lead to lower prices. The experience of OECD countries, such as the UK, the Netherlands and France, show that such alternative tariff-setting methodologies - such as price- and revenue-cap regulation - strengthens competitive pressures and contribute to curtail tariff inflation (Sappington andWeisman, 2010; Mirrlees-Black, 2014). By setting limits to the tariffs regulated companies may charge, or the revenues they may earn, price- and revenue-cap regulation replicate the discipline of competitive market forces and compel regulated firms to search for productivity gains.

The experience of OECD countries also suggests that price cap regulation coupled with independent regulators promotes infrastructure investment (Égert, 2009). State-owned enterprises still play a dominant role in many key sectors of the economy, such as banking, network industries (excluding airlines) and petroleum products. A preliminary count of SOEs by the government following OECD criteria reaches about 40 SOEs. Most of these SOEs have been created by specific laws determining their way of work, and regulations and procedures for reporting to the central government. They have drastically different organisational forms as some are public corporations - such as ICE (electricity and telecommunications), RECOPE (petroleum products), INS (insurance) - while others are non-state public enterprises and entities - such as (non-state-owned) public banks and financial institutions, the trade promotion agency and professional associations - or non-corporatised decentralised institutions - such as CCSS (the social security funds). Setting a more uniform set of regulations and procedures for reporting to the central government would be a start to rationalise their operations. Adherence to the OECD Guidelines on 
Corporate Governance of State-owned Enterprises (OECD, 2015c) would represent the first step to institute more transparent communication channels between the executive and the board and strengthen incentives to improve performance and accountability of senior management. Boosting access to credit through stronger competition in the banking sector

\section{Boosting access to credit through stronger competition in the banking sector}

In the banking sector, significant regulatory asymmetries hinder full competition between public and private banks contributing to high interest rates for borrowers. Empirical evidence suggests that high interest rate spreads can be ascribed to limited competition in the banking sector (Demirguc-Kunt and Huizinga, 1999; Demirguc-Kunt, Laeven, and Levine 2004). Costa Rican interest rate spreads are indeed among the highest in Latin America, just after Brazil, and substantially higher than the OECD country average (Figure 17). Also, the negative correlation between interest rate spreads and bank lending as percentage of GDP) suggests that the lack of competition in the Costa Rican banking sector is curtailing access to bank credits (Figure 17).

A large micro-econometric literature has shown that a more competitive banking sector is positively associated with access to bank credits (World Bank, 2013). For instance Demirguc-Kunt and Huizinga (1999) find that weak bank competition is positively associated with high bank spreads and profits across countries. Using data on net interest margins and overhead costs for over 1400 banks in 72 developed and developing economies, Demirguc-Kunt, Laeven, and Levine (2004) find that tighter regulations on bank entry and bank activities lead to higher costs of financial intermediation. 
Figure 17. High banking interest rate spreads curtail credit availability

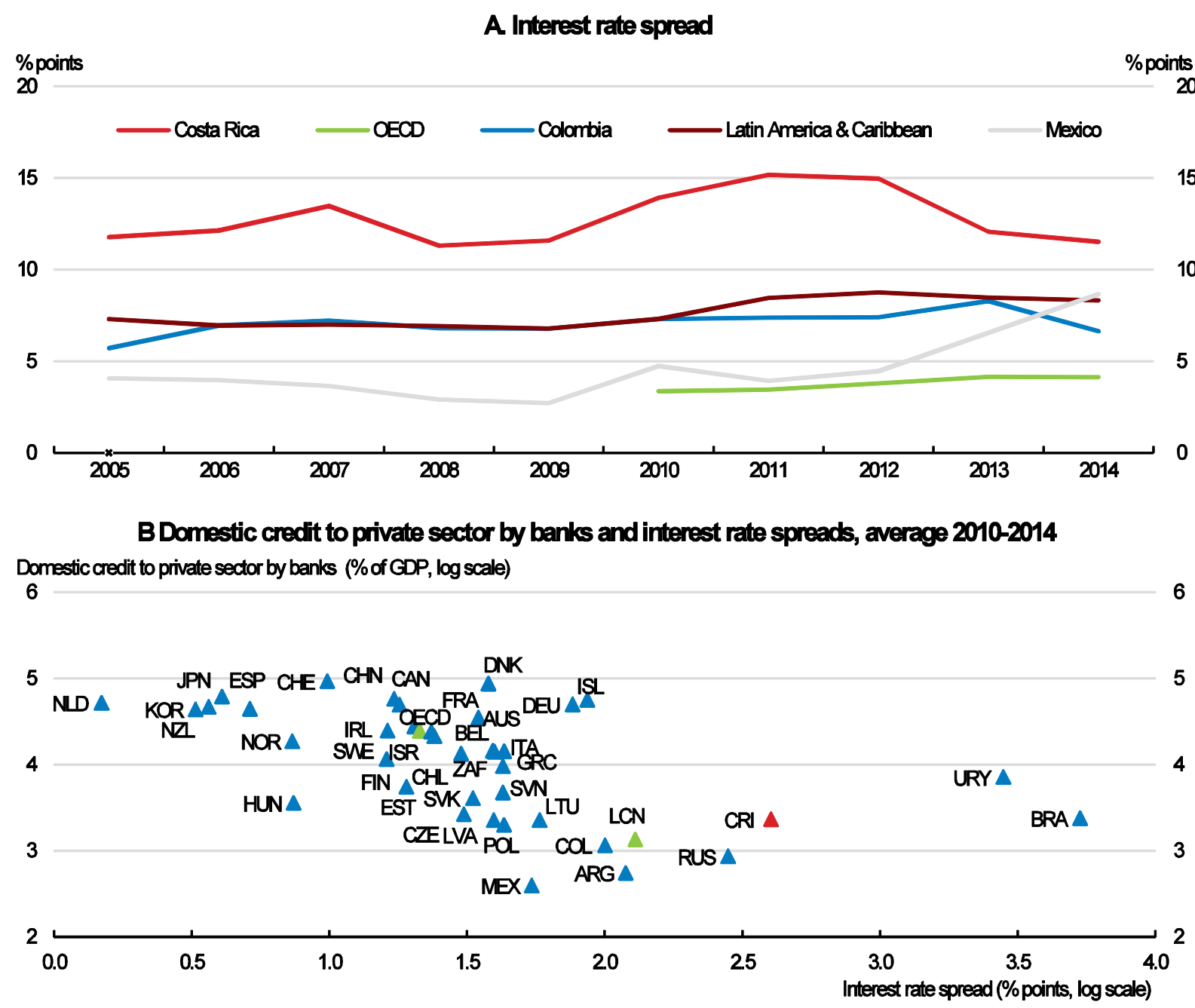

Note: Interest rate spread is calculated as the lending rate minus the deposit rate. LCN stands for Latin America and the Caribbean (all income levels) as defined by the World Bank.

Source: World Bank, World Development Indicators.

Restricted access to bank credits is especially problematic for small firms - as they need external capital to grow. Also, difficulties in accessing credit inhibit export market participation - as fixed costs of exports are an important barrier to start exporting for financially constrained firms (Dalberg, 2011; Manova, 2013; Manova et al., 2014); Costa Rican companies also cite difficult access to credit as an obstacle to establish links with foreign affiliates (Monge-Gonzáles et al., 2010).

One factor limiting competition in the banking sector is the large role that state-owned banks still play. The three state-owned banks (Banco Nacional de Costa Rica, Banco de Costa Rica, Banco Crédito Agrícola de Cartago) are less efficient than private banks, as gauged for example by the their higher ratio of administrative costs to total assets and liabilities, and pay higher average wage (Figure 18). Despite this, in mid-2015 state-owned banks still managed more than 50\% of the assets and liabilities of the banking sector. The pervasive role of state-owned banks is attributable to regulatory asymmetries, which hinder full competition between public and private banks. State-owned banks enjoy a government guarantee on bank deposits (amounting to more than 20\% of GDP) that private banks do not; also private banks are obliged to 
lend to the Fondo de Crédito para el Desarrollo (Development Credit Fund) for an amount equivalent to $17 \%$ of their demand deposits and all public institutions are obliged by law to deposit their cash with one of the state-owned banks. That in November 2015 the government issued a directive instructing stateowned banks to increase their efficiency - mainly by cutting administrative expenses - and reduce their intermediation margin by at least one percentage point by 2018 (La Gaceta, 2015) is indicative of the lack of strong competitive pressures in the banking sector. Regulatory asymmetries favouring state-owned banks should be eliminated as they also violate the OECD competitive neutrality principle, whereby no entity operating in an economic market must be subject to undue competitive advantages or disadvantages because of its ownership (OECD, 2012d).

Figure 18. State-owned banks are less efficient than private banks and pay higher average wage

B. Banks' Administrative costs over total assets

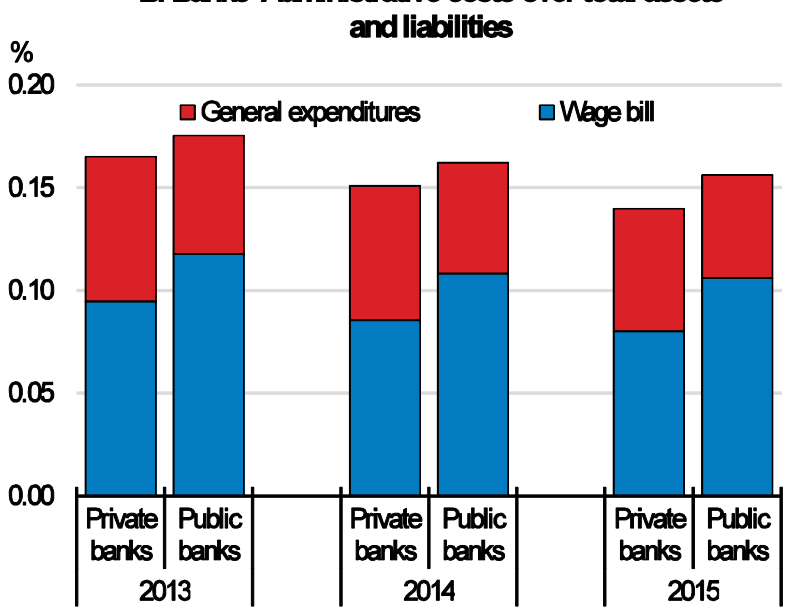

B. Average annual wage per employee

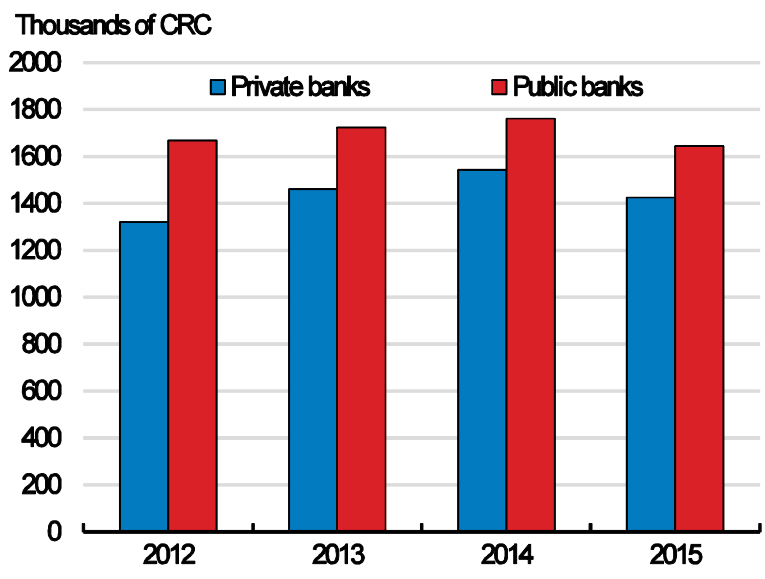

Note: The bars show the median of private and public banks' monthly administrative costs (general and personnel expenditures) expressed as percentage of the sum of total assets and liabilities; the ratio of the monthly administrative costs to the sum of total assets and liabilities are averaged over the year; data for 2015 are from January to September. Source: Superintendencia General de Entidades Financieras (SUGEFE).

Costa Rica has ample room to enhance banking competition by promoting market contestability. Studies on the banking sector suggest that contestability is more important than market structure in explaining the strength of competition (OECD, 2010b).With the right regulatory framework, strong competition among banks need not undermine financial stability. The OECD Competition Committee has indeed argued that designing and applying effective regulations and supervisory practices - rather than limiting bank competition - is the best conduit to banking stability, although striking the right balance between strong competition in and stability of the banking sector remains a challenge (OECD, 2010b; OECD, 2011).

The state can facilitate bank competition in different ways (World Bank, 2013; OECD, 2011). First it can facilitate the entry of well-capitalised institutions and timely exit of insolvent ones. Fewer restrictions to entry and activity lead to stronger competition. In this respect Costa Rica fareswell compared to peers as restrictions to entry are limited. In the five year up to 2010 no request for a banking licence was denied (Cihak et al., 2012). However, the financial sector is outside the purview of the competition agency.The latter can express only non-binding opinions on mergers between banks, which are eventually approved or not by the Regulatory Authority of Financial Entities (SUGEF). As underlined in a previous OECD (2014a) study, to strengthen the competitive setting of the banking sector it is opportune to transfer to a reformed COPROCOM the power to authorise merger transactions between market players in the financial sector and leaving to SUGEF the authority to issue nonbinding opinions and forbid mergers only on financial stability grounds. 
Second, the state can promote credit-information sharing services on potential borrowers and consumers and institute depositor protection schemes. Credit bureaus increase competitive pressures by reducing asymmetric information between banks' current customers and other potential financial service suppliers (Dell'Ariccia, Friedman, and Marquez, 1999). In this respect Costa Rica fares well as it has private and public credit bureaus providing comprehensive information on potential borrowers. As highlighted above, Costa Rica, however, has yet to establish a system-wide deposit insurance scheme, as the current one covers only state-owned banks. Establishing a system-wide deposit insurance scheme would contribute to a level-playing field among banks and reinforce banking sector's stability (Anginer et al., 2014). Only few OECD or Latin America countries do not have an explicit deposit insurance scheme (Demirguc-Kunt et al., 2014).

Third, improving the governance and management of state-owned banks, similarly to other SOEs, would improve transparency and efficiency. A large literature has shown that since state-owned banks often enjoy a dominant position and benefit from implicit or explicit government subsidies they undermine the banking sector's competition, stability and the degree of financial development of the country (Barth et al., 2004; La Porta et al., 2002). Adherence to the OECD Guidelines on Corporate Governance of Stateowned Enterprises (OECD, 2015c) would be a first step to improve state-owned banks' corporate governance. Eventually, once public banks are operating according to higher standards of governance and corporate performance, the authorities should assess whether or not maintaining public ownership of a large share of the banking industry is justified on economic, social and financial stability grounds. Reducing the State's equity stake in reformed state-owned banks could free resources that could be used more effectively to pursue economic and social objectives. The government should eventually consider keeping only a single state-owned bank with an explicit and clear public mandate to overcome market failures, such as promoting infrastructure investment. A survey of development banks (i.e. state-owned banks with a public mandate) reveals that to be effective developing banks need to have a clear and sustainable mandate and sound corporate governance practices (de Luna-Martinez and Vicente, 2012). The UK's Green Investment Bank is an example of a recently established and well-managed development bank.

\section{Improving transport infrastructure}

Better transport infrastructure can contribute to higher productivity through various channels. First, it can boost the productivity of private inputs because of complementarities with labour and the private capital stock. For instance, improved transport links will widen employment opportunities, resulting in a more efficient allocation of labour. Second, the higher productivity of the private capital stock would boost private investment (Agénor and Moreno-Dodson, 2006). Third, better transport infrastructure can support more environmentally sustainable growth and mobility patterns. Better integrating physical transport infrastructure plans with land-use and social policies can raise well-being and social welfare, by reducing commuting times and contributing to green and inclusive growth (OECD, 2014b,c). People with longer commuting time report systematically lower subjective well-being (Stutzer and Frey, 2008).

Assessing the quality and quantity of infrastructure is notoriously difficult, as there are no comprehensive internationally comparable data based on objective criteria (Pisu et al., 2012). Survey data on the perceived quality of infrastructure rank Costa Rica $103^{\text {rd }}$ worldwide. It is also below Latin America average for roads, ports and railroads, although above it for airports (Figure 19). 
Figure 19. There is scope to improve the quality of transport infrastructure

\section{A. Roads}

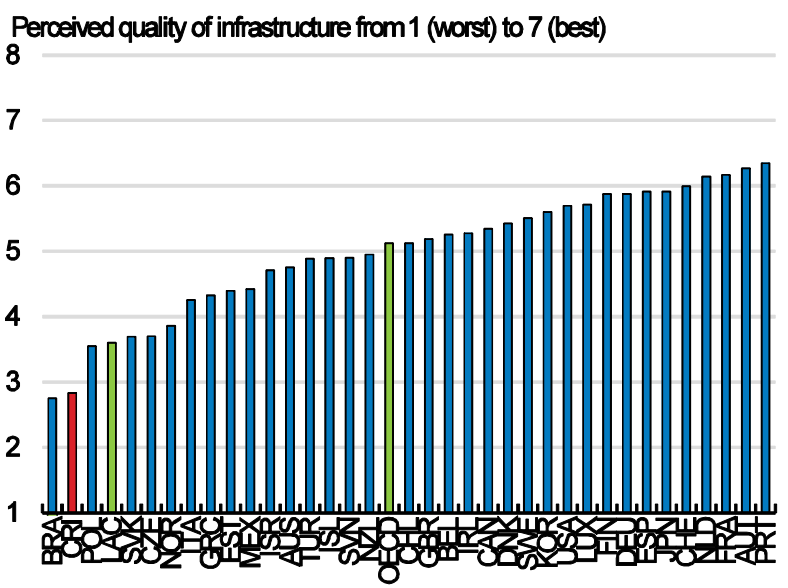

C. Railroad

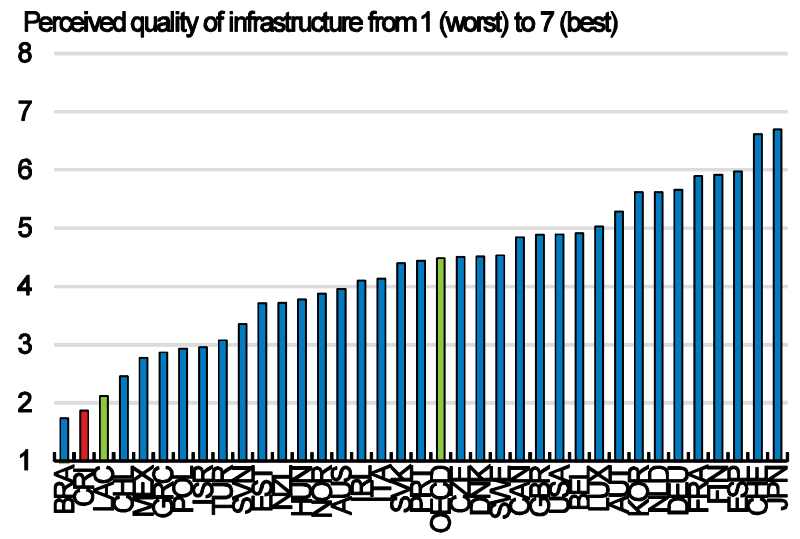

B. Ports

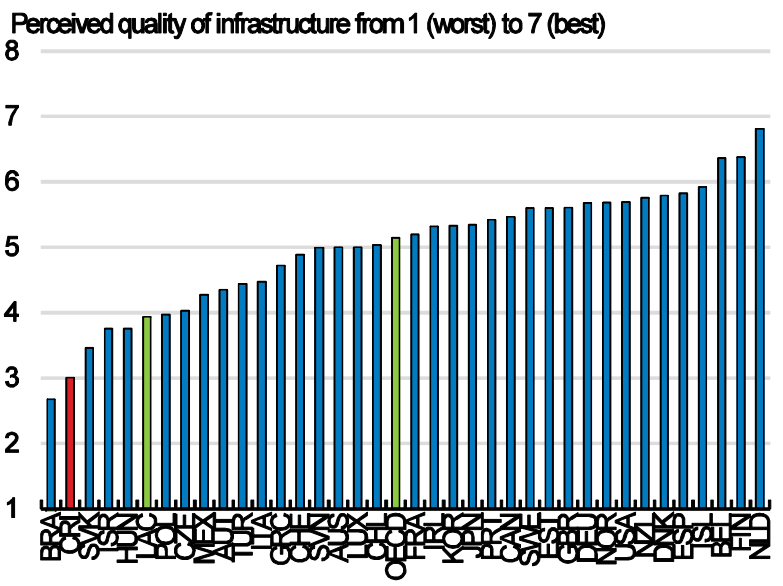

D. Air transport

Perceived quality of infrastructure from 1 (worst) to 7 (best)

8

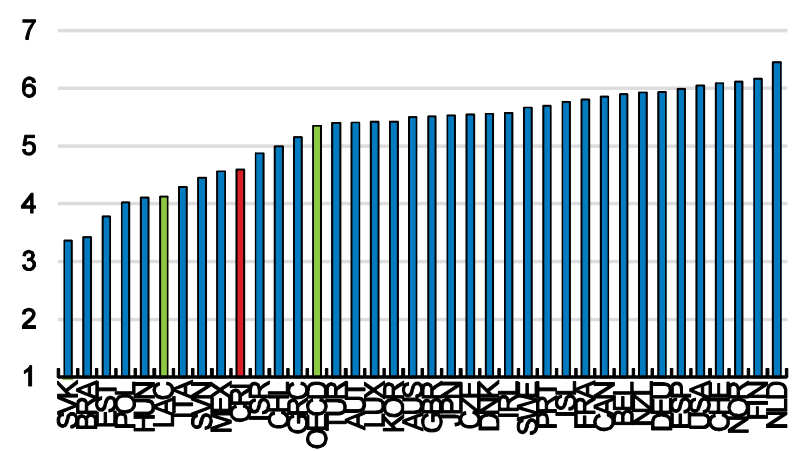

Note: Figures refer to the following question: How would you assess general infrastructure in your country (from $1=$ extremely underdeveloped - among the worst in the world to 7 = extensive and efficient - among the best in the world)? The OECD and Latin America \& Caribbean (LAC) aggregate are calculated as an unweighted average.

Source: World Economic Forum, The Global Competitiveness Index Historical Dataset @ 2005-2015.

The road network is well developed and is nearly $43000 \mathrm{~km}$ long (Table 1$)$. Nearly $20 \%$ (8 $000 \mathrm{~km})$ of the road network are part of the national road network which is maintained by the National Roads Council (CONAVI). The remaining roads are part of the cantonal road network, maintained by municipalities (Table1). Compared to peers, Costa Rican road network is extensive as it counts $84 \mathrm{~km}$ per 100 square $\mathrm{km}$ of land, four times the average for Latin America (World Bank, 2012). However, road quality is low; according to a national inventory, $62 \%$ of roads show deficient or very deficient conditions, $33 \%$ are in regular condition, $5 \%$ in good condition and none is in very good condition (LANAMMEUCR, 2015). Most bridges are at structural risk of collapsing due to natural deterioration. Despite the low quality of the road network, the number of vehicles in circulation rose to by $68 \%$ from 2003 to 2014 (MOPT, 2014).

Accordingly, one of the main priorities of the National Transport Plan 2011-35 is the rehabilitation and expansion of the road network. This is welcome given the importance of roads in Costa Rican transport system as the railways system is underdeveloped. In urban areas, there are no realistic alternative to cars and buses. Besides, dedicated bicycle lanes and wide sidewalks are rare. The maintenance programme appears to be working well as between 2011 and 2014 it has reached and surpassed its goals (CONAVI, 2015). 
Table 1. Costa Rica road network is extensive

2014

\begin{tabular}{lccc}
\hline Road Network & National $(\mathbf{k m})$ & Municipal $(\mathbf{k m})$ & Total $(\mathbf{k m})$ \\
\hline Paved & 5,269 & 6,547 & $\mathbf{1 1 , 8 1 6}$ \\
Graved or Dirt & 2,512 & 28,540 & $\mathbf{3 1 , 0 5 2}$ \\
Total & $\mathbf{7 , 7 8 1}$ & $\mathbf{3 5 , 0 8 7}$ & $\mathbf{4 2 , 8 6 8}$ \\
\hline
\end{tabular}

Source: MOPT (2014) and LANAMMEUCR (2015).

In the second half of the 1990s, the government decided to close the railways system down. The decision was reversed some years later (MOPT, 2011) and railways tracks are being rehabilitated and routes reopened. Since 2005, limited urban and interurban railways services have started again in the metropolitan area of San Jose (Table2). However, improvements in railways services have been uneven as routes were reopened without performing demand analyses, there are no procedures to collect and compute demand statistics, no clear standards to ensure quality of services and no modern information and communication technologies (CGR, 2014).

Table 2. The railways system is slowly being reactivated.

Routes in the Great Metropolitan Area of San Jose, 2014

\begin{tabular}{lcc}
\hline \multicolumn{1}{r}{ Locations connected } & Km & Started operations \\
\hline Pavas-San Pedro & $\mathbf{8 . 0}$ & 2005 \\
\hline Heredia-San José & 9.6 & 2009 \\
San Pedro-Curridabat & 6.8 & 2010 \\
Belén-San José & 14.4 & 2011 \\
Cartago-San José & 20.6 & 2013 \\
Total & 59.4 & \\
\hline
\end{tabular}

Source: CGR (2014).

A long standing plan of developing a sorely needed mass rapid transit system in the Great Metropolitan Area (GAM) of San Jose - where half of the population lives - has made no actual progress. The latest proposal by INCOFER would cost USD 1400 million and be completed by October 2022 (INCOFER, 2014). About 75\% of all passenger traffic in the GAM relies on public transport, mostly buses as the role of railways is marginal (MOPT, 2011). The mass rapid transit system and, more generally, the improvement of the railway, are paramount to reduce road transport congestion and pollution.

Positive steps have recently been taken to ameliorate seaports and airports. In 2015, the GrainTerminal of Caldera Port was inaugurated and the construction phase of the Moin Container Terminal was started in the Caribbean coast. Both projects were executed through concession schemes. In airports, the private-sector participation has also been relevant. The Juan Santamaria International Airport (USD 138 million) was modernised and expanded, and the Passenger Terminal of the Liberia International Airport (USD 35 million) was inaugurated.

\section{The transport-infrastructure spending gap is large}

The overall low quality of Cost Rica's transport infrastructure is attributable to chronic underspending compounded by deficient strategic planning and lack of a long-term vision for the sector. From 2002 to 2013, transport infrastructure spending averaged $0.8 \%$ of GDP less than the OECD average (Figure 20). In addition, spending has been irregular as in the absence of a multiyear budgeting process, public investment in transport infrastructure is negotiated every year and subject to cuts (MOPT, 2011). 
The government is aware of the transport infrastructure spending shortfall and the National Transport Plan 2011-35 (MOPT, 2011) projects annual infrastructure spending needs of about 4\% of GDP to 2035 (2.45\% of GDP between 2011-18 and 4\% between 2019-35). According to the Plan, one third of the estimated spending needs should be financed by the public budget with the remaining part coming from the private sector.

Figure 20. Transport infrastructure spending has been below OECD average

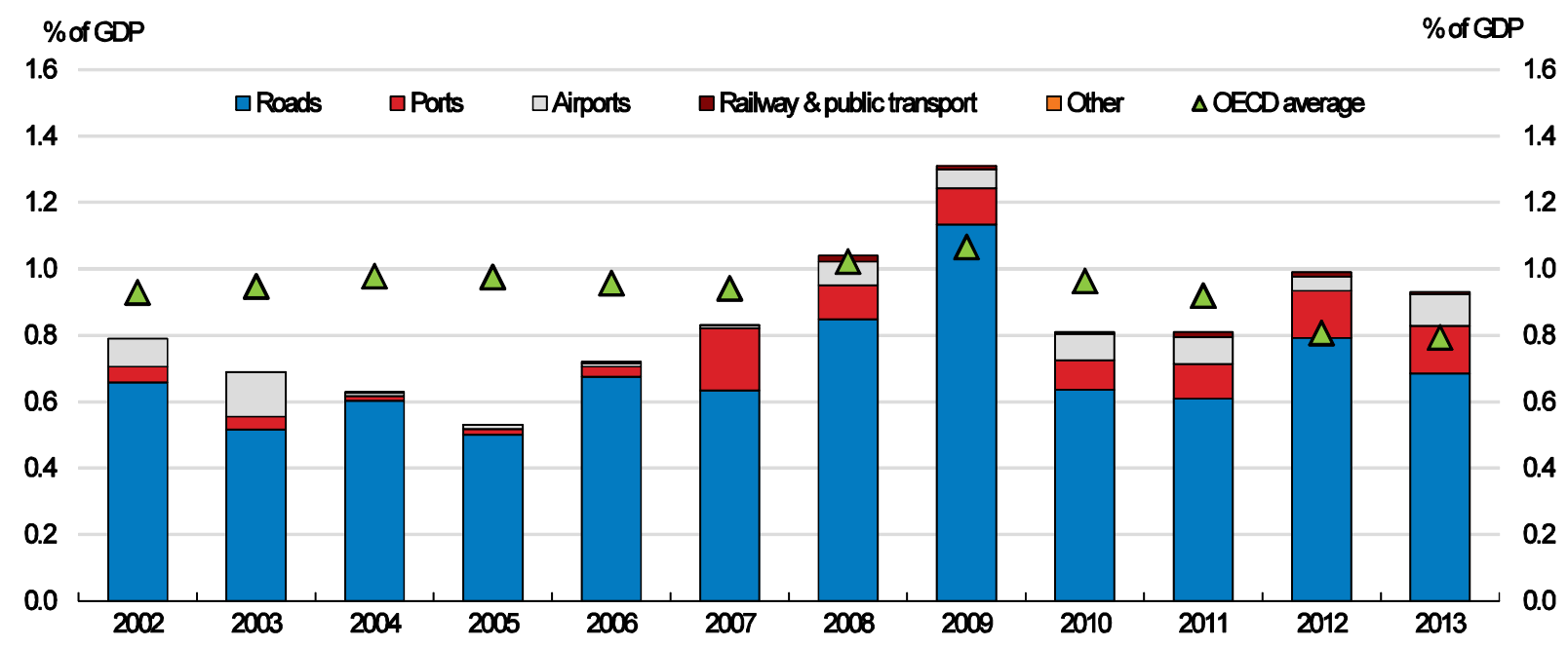

Note: Data for Chile and Israel is not available. OECD is an unweighted average.

Source: OECD calculations based on MOPT (2014, 2011), ECLAC (2014) and OECD Transport Infrastructure Investment and Maintenance Spending Database.

\section{The institutional framework needs be simplified}

The transport infrastructure planning and decision making processes are highly fragmented among different ministries and government agencies (Table3). The Ministry of PublicWorks (MOPT) is the institution that has historically been in charge of planning, building, maintaining and operating transport infrastructure.The creation in the late 1990s of independent and semi-independent agencies with ample administrative freedom and decision powers over specific issues has diminished its role. The rational of this move was to free the Ministry of Public Works from project execution so as it could focus on policy developments. The agencies that were created are: CONAVI, with responsibilities for extending and maintaining the national road network; $\mathrm{CNC}$, which promotes and manages concession projects - across the whole infrastructure sector; and CTP, responsible for policies relating to public road transport (i.e. taxis, buses and coaches). Other important government bodies having crucial roles in transport infrastructure are: the National Railways Institute (INCOFER), which manages and operates the railways system; the Costa Rican Institute for Pacific Ports (INCOP) and the Port Management Board of the Atlantic Coast Development (JAPDEVA), which are port authorities and operators of the Pacific and Caribbean seaports, respectively; the Technical Civil Aviation Council (CETAC) and the Road Safety Council (COSEVI) formulate policies for civil aviation and road safety. Finally, other public institutions have horizontal roles. These include the Regulatory Authority of Public Services (ARESEP), with responsibilities for fixing tariffs for buses, taxis, trains and ports, and the National Environmental Office (SETENA) - within the Ministry of Environment and Energy for assessing infrastructure projects' environmental impacts. Finally, the Ministry of Finance plays a marginal role in the transport infrastructure as it does not actively participate in setting policy directions, project preparation, evaluation and prioritisation. Its role is mainly limited to authorizing tax exemptions to incentivise private-sector participation. 
The establishment of executing agencies as distinct from policy-design agencies (i.e. ministries) is in line with the New Public Management ideas developed in the 1980s and 1990s in the attempt to boost the efficiency of the public administration (OECD, 2015a). In general, such a separation between policy design and execution, although sensible and based on sound governance principles, can undermine the ability of the ministry to steer and control executing agencies based on their outputs (OECD, 2015a). In the case of Costa Rica, this may be one of the reasons why public infrastructure projects are often the result of individual institutional efforts, do not follow common approaches and suffer from inadequate preparation (CGR, 2012).

The numerous public agencies and bodies involved in transport infrastructure contribute to excessive policy fragmentation and uncertainty. This impinges negatively on the overall policy coherence of the sector and contributes to delay projects execution. An analysis of 15 transport infrastructure projects found delays between three and ten years from the time the contractor is selected to the start of the construction (CGR, 2012). Some of the projects included in the CGR's study have accumulated over 20 years of delay since the project inception (e.g. San Jose-San Ramon project). Projects financed with funds from multilateral institutions are no exception, resulting in large amount of available but unspent funds (Pisu and Villalobos, forthcoming). The current administration is aware of the problem and is trying to recover MOPT's sector stewardship, through better planning, management, coordination, monitoring and evaluation of sector agencies.

Simplifying the complex institutional setting of the transport sector is a priority. Different agencies could be merged. At the minimum, better articulating the policy mandate of the different ministries and agencies on transport policies and coordinating the development and execution of policies would result in a more coherent policy framework and reduce delays. To overcome institutional fragmentation, some OECD countries have created dedicated agencies to develop long-term strategies and plans, such as Australia (Infrastructure Australia) and the United Kingdom (Infrastructure UK), with good results. In the Costa Rican institutional setting, an enhanced Presidential Council on Competitiveness and Innovation (CPCI) with a more strategy role could be tasked, with the Ministry of Public Works, to design long-term transport infrastructure strategies and policies, consistent with other long term economic and social objectives, and track progresses towards them. Strategic planning could help link transport infrastructure objectives with wider socio-economic and environmental benefits, making it less likely that public transport infrastructure spending be cut because of short-term budget and political pressures.

Additionally, the role of SOEs operating in transport infrastructure, especially in maritime and railways transport, should be reconsidered and their corporate governance improved following the OECD Guidelines on Corporate Governance of State-Owned Enterprises. A clear functional separation of SOEs' activities - between the regulation and the provision of infrastructure services in addition to vertical separation - can better prepare them for and encourage increased private-sector participation.

Careful cost-benefit analyses can improve project preparation and selection, but no agencies in Costa Rica perform them. The government should develop precise guidelines to conduct cost-benefit analyses in transport infrastructure and apply them systematically. The OECD report Cost-Benefit Analysis and the Environment (OECD, 2006) provides general principles to perform cost-benefit analysis taking into account environmental constraints. Overall no single model exists to perform reliable cost-benefit analyses but OECD countries have accumulated a diverse set of experiences (Persson and Song, 2010) that the government could draw upon. 


\section{Getting ready for more private investment}

Costa Rica has traditionally financed infrastructure projects via the government budget. The construction is often outsourced to a private contractor, while the government retains full ownership and management responsibility of the infrastructure stock. Only more recently, has Costa Rica used private participation in stages other than design and construction, as in the recent concessions of seaports and airports. Private participation in transport infrastructure requires a regulatory and institutional environment conducive to low regulatory and policy uncertainty. On a general level, international evidence suggests that private participation has been encouraged by a sound and transparent legal and institutional framework allowing for ample consultation with all stakeholders (Siemiatycki, 2013).

Only four projects involving private participation have materialised since the General Concession Law was passed in 1998 and updated in 2008 (Pisu and Villalobos, forthcoming). Two projects, the Metropolitan Electric Train and Route San Jose-San Ramon, were suspended because of political and popular discontent. Furthermore, the projects that were signed suffered from up to 11-year delays from the bidding process to the beginning of the construction phase. Often delays were due to a slow and confusing expropriation process resulting in judicial proceedings (MOPT, 2011).

The National Concession Council (CNC) is responsible for promoting private-sector participation in infrastructure. Its roles involve the approval of tender documentation, designing and managing the bidding selection process, signing concession contracts as representative of the central government, acting as regulator by managing and monitoring concession contracts. Its budget (USD 15 million for 2015) is funded for $90 \%$ by central government with the remaining part coming from fees charged on concessionaries. This contrasts with OECD best practice as the funding, scope and assessment of dedicated PPP units should not create incentives favouring the creation of PPPs (OECD, 2010a). CNC should be funded $100 \%$ by the central government.

The weak performance of CNC in promoting concessions and PPPs is partly attributable to it being an agency within the Ministry of PublicWorks. This differs from OECD practice, where PPP units mostly depend on the Ministry of Finance (OECD, 2010a). The current arrangement in Costa Rica may create a bias against private participation in infrastructure because the Ministry of Public Works also promotes public-funded infrastructure projects that can be in direct competition with privately funded ones.

In addition to promoting private participation in transport infrastructure, CNC should be directly involved in project preparation and selection - with inputs from the Ministry of PublicWorks covering projects' technical aspects - and perform or coordinate cost-benefit analyses. Moving CNC to the Ministry of Finance could improve performance and would facilitate the accounting of implicit liabilities arising from private-sector participation, which currently Costa Rica does not undertake (Irwin, 2007; Posner et al., 2009). It is important to ensure PPPs are affordable over the long term, which requires a clearer link between the PPP procurement process and the central authority's budget process. 
Table 3. The transports sector suffers from institutional fragmentation

\begin{tabular}{|c|c|c|c|c|}
\hline Institution & Type (budget allocation) & $\begin{array}{l}\text { Year of } \\
\text { creation }\end{array}$ & $\begin{array}{c}\text { Governing } \\
\text { Law }\end{array}$ & Responsibilities \\
\hline \multicolumn{5}{|c|}{ Institutions with specific responsibility for the transport infrastructure sector } \\
\hline Ministry of Public Works (MOPT) & Ministry (Central government) & 1963 & No.3155 & $\begin{array}{c}\text { Planning agency; issue the National } \\
\text { Transport Plan }\end{array}$ \\
\hline Technical Civil Aviation Council (CETAC) & De-concentrated agency under MOPT & 1973 & No.5150 & $\begin{array}{l}\text { Issuing regulations on civil aviation } \\
\text { and national airports. }\end{array}$ \\
\hline Road Safety Council (COSEVI) & De-concentrated agency under MOPT & 1979 & No.6324 & $\begin{array}{l}\text { Issuing regulations to increase the } \\
\text { safety of the road transports }\end{array}$ \\
\hline National Concessions Council (CNC) & De-concentrated agency under MOPT & 1998 & No.7762 & $\begin{array}{l}\text { Promoting private participation } \\
\text { through concessions and PPPs }\end{array}$ \\
\hline National Road Council (CONAVI) & De-concentrated agency under MOPT & 1998 & No.7798 & $\begin{array}{l}\text { Building and maintaining the road } \\
\text { network }\end{array}$ \\
\hline Public Transportation Council (CTP) & De-concentrated agency under MOPT & 1999 & No.7969 & $\begin{array}{l}\text { Issuing regulations relating to public } \\
\text { road transport (i.e. taxis, buses and } \\
\text { coaches) }\end{array}$ \\
\hline $\begin{array}{l}\text { Costa Rican Institute of Pacific Ports } \\
\text { (INCOP) }\end{array}$ & Non-financial pubic company & 1953 & No.1721 & Port authorities for Pacific ports \\
\hline $\begin{array}{l}\text { Port Management Board of the Atlantic } \\
\text { Coast Development (JAPDEVA) }\end{array}$ & Non-financial pubic company & 1963 & No.3091 & Port authorities for Atlantic ports \\
\hline National Railway Institute (INCOFER) & Non-financial pubic company & 1985 & No.7001 & $\begin{array}{l}\text { Managing the railways system } \\
\text { (stations, tracks and rolling stock) }\end{array}$ \\
\hline \multicolumn{5}{|c|}{ Institutions with an horizontal role } \\
\hline $\begin{array}{l}\text { Regulatory Authority of Public Services } \\
\text { (ARESEP) }\end{array}$ & De-centralised institution & 1928 & No.7593 & $\begin{array}{l}\text { Setting tariffs for buses, taxis, trains } \\
\text { and ports }\end{array}$ \\
\hline Ministry of Planning (MIDEPLAN) & Ministry & 1974 & No. 5525 & $\begin{array}{l}\text { Coordinating agency and issuing the } \\
\text { National Development Plan }\end{array}$ \\
\hline Ministry of Finance & Ministry & 1885 & $\begin{array}{l}\text { Decree No. } \\
\quad 55\end{array}$ & $\begin{array}{l}\text { Authorizing tax exemptions to } \\
\text { incentivize private-sector } \\
\text { participation }\end{array}$ \\
\hline $\begin{array}{l}\text { Ministry of Environment and Energy } \\
\text { (MINAE) }\end{array}$ & Ministry & 1990 & No.7152 & \\
\hline $\begin{array}{l}\text { National Environmental Office } \\
\text { (SETENA) }\end{array}$ & De-concentrated agency under MINAE & 1995 & No. 7554 & Issuing environmental permits \\
\hline
\end{tabular}

Source: Elaboration based on MIDEPLAN (2007) and Ministry of Finance (2014). 
A more widespread deployment of user charges would encourage higher private sector involvement in infrastructure. Currently, user charges are underutilised in Costa Rica, especially in the road sector where they could be highly beneficial from both an economic and environmental standpoint. In addition to providing a revenue stream to road operators user-paid tolls would promote a more rational use of infrastructure and alternative mode of transport. User paid toll roads - and more in general cost-recoverylevel user charges - are often opposed on equity grounds as they tend to be regressive.Targeted social transfers are an effective way to tackle these concerns. The recent VAT refund envisaged in the context VAT reform is a promising step in this direction, which could also be extended to compensate poor families for higher user charges.

Developing a transport-infrastructure project pipeline would be conducive to higher private sector participation by lowering investment uncertainty and facilitate investors' planning and decision-making process. It would help de-politicise decisions on project selection and execution, and instead base them on engineering and economic considerations. The United Kingdom is a recent example of a successful attempt to create an infrastructure project pipeline managed by an agency (Infrastructure UK) within the Ministry of Finance (Pisu, Pels and Bottini, 2015).

Overall, the OECD Principles for Private Sector Participation in Infrastructure (OECD, 2007) offers basic broad rules that can be useful to attract more private investment in infrastructure while also managing the ensuing risks. Table4 shows that in many respects Costa Rica falls short of these principles and the reforms needed to move towards them. 
ECO/WKP(2016)42

Table 4. OECD Principles for Private Sector Participation in Infrastructure and Costa Rica's practices

\begin{tabular}{|c|c|c|}
\hline Principle & OECD Guidelines & Costa Rica \\
\hline \multicolumn{3}{|c|}{ Deciding on public or private provision of infrastructure services } \\
\hline 1 & $\begin{array}{l}\text { The choice by public authorities between public and private provision } \\
\text { should be based on cost-benefit analysis taking into account all } \\
\text { alternative modes or delivery, the full system of infrastructure provision, } \\
\text { and the projected financial and non-financial costs and benefits over the } \\
\text { project lifecycle. }\end{array}$ & $\begin{array}{l}\text { No cost-benefit analyses are performed } \\
\text { in Costa Rica. Choices are is } \\
\text { susceptible to political interference anc } \\
\text { changes following government changes. }\end{array}$ \\
\hline 2 & $\begin{array}{l}\text { No infrastructure project-regardless of the degree if private involvement } \\
\text {-should be embarked upon without assessing the degree to which its } \\
\text { costs can be recovered from end-users and, in case of shortfalls, what } \\
\text { other sources of finance can be mobilized. }\end{array}$ & $\begin{array}{l}\text { The role of Ministry of Finance has } \\
\text { been traditionally limited to authorizing } \\
\text { tax exemptions for project } \\
\text { development. }\end{array}$ \\
\hline 3 & $\begin{array}{l}\text { The allocation of risk between private parties and the public sector will } \\
\text { be largely determined by the chosen model of private sector } \\
\text { involvement, including the allocation of responsibilities. The selection of } \\
\text { a particular model and an associated allocation of risk should be based } \\
\text { upon an assessment of the public interest. }\end{array}$ & $\begin{array}{l}\text { Lack of mandatory guidelines for public } \\
\text { sector institutions to decide whether a } \\
\text { project is procured by concession or } \\
\text { through the traditional scheme and how } \\
\text { to allocate risks }\end{array}$ \\
\hline 4 & $\begin{array}{l}\text { Fiscal discipline and transparency must be safeguarded, and the potential } \\
\text { public finance implications of sharing responsibilities for infrastructure } \\
\text { with the private sector fully understood. }\end{array}$ & $\begin{array}{l}\text { Limited involvement of Ministry of } \\
\text { Finance in structuring concessions. }\end{array}$ \\
\hline \multicolumn{3}{|c|}{ Enhancing the enabling institutional environment } \\
\hline 5 & $\begin{array}{l}\text { A sound enabling environment for infrastructure investment, which } \\
\text { implies high standards of public and corporate governance, transparency } \\
\text { and the rule of law, including protection of property and contractual } \\
\text { rights, is essential to attract the participation of the private sector. }\end{array}$ & $\begin{array}{l}\text { Weak leading institution }(\mathrm{CNC}) \text { and no } \\
\text { clear rules for investors. There are no } \\
\text { standardized contracts; the government } \\
\text { has often missed contract deadlines. }\end{array}$ \\
\hline 6 & $\begin{array}{l}\text { Infrastructure projects should be free from corruption at all levels and in } \\
\text { all project phases. Public authorities should take effective measures to } \\
\text { ensure public and private sector integrity and accountability and } \\
\text { establish appropriate procedures to deter, detect and sanction corruption. }\end{array}$ & $\begin{array}{l}\text { Strong institutional control by the } \\
\text { Comptroller General. }\end{array}$ \\
\hline 7 & $\begin{array}{l}\text { The benefits of private sector participation in infrastructure are enhanced } \\
\text { by efforts to create a competitive environment, including by subjecting } \\
\text { activities to appropriate commercial pressures, dismantling unnecessary } \\
\text { barriers to entry and implementing and enforcing adequate competition } \\
\text { laws. }\end{array}$ & $\begin{array}{l}\text { Barriers to competition are high in the } \\
\text { infrastructure sector; the absence of a } \\
\text { reliable project pipeline and weak } \\
\text { institutional environment have resulted } \\
\text { in limited offers in bidding processes. }\end{array}$ \\
\hline 8 & $\begin{array}{l}\text { Access to capital markets to fund operations is essential to private sector } \\
\text { participants. Restrictions in access to local markets and obstacles to } \\
\text { international capital movements should, taking into account } \\
\text { macroeconomic policy considerations, be phased out. }\end{array}$ & $\begin{array}{l}\text { There are no restrictions to access the } \\
\text { capital market but the capital market is } \\
\text { small The long-standing tradition of } \\
\text { funding projects through government } \\
\text { budget has inhibited its development. }\end{array}$ \\
\hline \multicolumn{3}{|c|}{ Goals, strategies and capacities at all levels } \\
\hline 9 & $\begin{array}{l}\text { Public authorities should ensure adequate consultation with end-users } \\
\text { and other stakeholders including prior to the initiation of an } \\
\text { infrastructure project. }\end{array}$ & $\begin{array}{l}\text { Poor stakeholder management has } \\
\text { resulted in opposition to private } \\
\text { participation and project execution } \\
\text { delays }\end{array}$ \\
\hline 10 & $\begin{array}{l}\text { Authorities responsible for privately-operated infrastructure projects } \\
\text { should have the capacity to manage the commercial processes involved } \\
\text { and to partner on an equal basis with their private sector counterparts. }\end{array}$ & $\begin{array}{l}\text { CNC suffers from human capital } \\
\text { limitations due to non-competitive pay } \\
\text { scale; the Board of Directors does not } \\
\text { contribute to CNC's effectiveness and } \\
\text { efficiency. }\end{array}$ \\
\hline 11 & $\begin{array}{l}\text { Strategies for private sector participation in infrastructure need to be } \\
\text { understood, and objectives shared, throughout all levels of government } \\
\text { and in all relevant parts of the public administration. }\end{array}$ & $\begin{array}{l}\text { CNC has limited communication and } \\
\text { knowledge-sharing with other public } \\
\text { sector institutions. }\end{array}$ \\
\hline 12 & $\begin{array}{l}\text { Mechanisms for cross-jurisdictional co-operation, including at the } \\
\text { regional level, may have to be established. }\end{array}$ & $\begin{array}{l}\text { There is no policy to strengthen local } \\
\text { governments' capacity. }\end{array}$ \\
\hline \multicolumn{3}{|c|}{ Making the public-private co-operation work } \\
\hline 13 & $\begin{array}{l}\text { To optimize the involvement of the private sector, public authorities } \\
\text { should communicate clearly the objectives of their infrastructure policies } \\
\text { and they should put in place mechanisms for consultations between the } \\
\text { public and private partners regarding these objectives as well as } \\
\text { individual projects. }\end{array}$ & $\begin{array}{l}\text { There is no overall infrastructure } \\
\text { strategy, reliable project pipeline, clear } \\
\text { rules and certainty on the continuity of } \\
\text { projects. }\end{array}$ \\
\hline
\end{tabular}




\begin{tabular}{|c|c|c|}
\hline 14 & $\begin{array}{l}\text { There should be full disclosure of all project-relevant information } \\
\text { between public authorities and their private partners, including the state } \\
\text { of pre-existing infrastructure, performance standards and penalties in the } \\
\text { case of non-compliance. The principle of due diligence must be upheld. }\end{array}$ & $\begin{array}{l}\text { No clear rules for information sharing } \\
\text { with the private sector. }\end{array}$ \\
\hline 15 & $\begin{array}{l}\text { The awarding of infrastructure contracts or concessions should be } \\
\text { designed to guarantee procedural fairness, non-discrimination and } \\
\text { transparency. }\end{array}$ & $\begin{array}{l}\text { Lack of credible pipeline, unclear rules } \\
\text { and non-standardized contracts } \\
\text { diminish competition. }\end{array}$ \\
\hline 16 & $\begin{array}{l}\text { The formal agreement between authorities and private sector participants } \\
\text { should be specified in terms of verifiable infrastructure services to be } \\
\text { provided to the public on the basis of output or performance based } \\
\text { specifications. It should contain provisions regarding responsibilities and } \\
\text { risk allocation in the case of unforeseen events. }\end{array}$ & $\begin{array}{l}\text { There are no standardized contracts to } \\
\text { guarantee that these elements are } \\
\text { included. }\end{array}$ \\
\hline 17 & $\begin{array}{l}\text { Regulation of infrastructure services needs to be entrusted to specialized } \\
\text { public authorities that are competent, well-resourced and shielded from } \\
\text { undue influence by the parties to infrastructure contracts. }\end{array}$ & $\begin{array}{l}\text { CNC's difficulties in promoting and } \\
\text { executing Costa Rica's concession } \\
\text { policy are due to poor project } \\
\text { management and failure to comply with } \\
\text { contract deadlines. }\end{array}$ \\
\hline 18 & $\begin{array}{l}\text { Occasional renegotiations are inevitable in long-term partnerships, but } \\
\text { they should be conducted in good faith, in a transparent and non- } \\
\text { discriminatory manner. }\end{array}$ & $\begin{array}{l}\text { Unclear rules encourage contract } \\
\text { renegotiation. }\end{array}$ \\
\hline 19 & $\begin{array}{l}\text { Dispute resolution mechanisms should be in place through which } \\
\text { disputes arising at any point in the lifetime of an infrastructure project } \\
\text { can be handled in a timely and impartial manner. }\end{array}$ & $\begin{array}{l}\text { Dispute resolution mechanisms are } \\
\text { included in contracts but deadlines are } \\
\text { often not specified. }\end{array}$ \\
\hline \multicolumn{3}{|c|}{ Encouraging responsible business conduct } \\
\hline 20 & $\begin{array}{l}\text { Private sector participants in infrastructure should observe commonly } \\
\text { agreed principles and standards for responsible business conduct. }\end{array}$ & $\begin{array}{l}\text { Private sector chambers do not clearly } \\
\text { communicate to stakeholder their } \\
\text { business conduct standards. }\end{array}$ \\
\hline 21 & $\begin{array}{l}\text { Private enterprises should participate in infrastructure projects in good } \\
\text { faith and with a commitment to fulfil their commitments. }\end{array}$ & $\begin{array}{l}\text { Private sector participation is perceived } \\
\text { negative by several citizen and political } \\
\text { sectors. }\end{array}$ \\
\hline 22 & $\begin{array}{l}\text { Private sector participants, their subcontractors and representatives } \\
\text { should not resort to bribery and other irregular practices to obtain } \\
\text { contracts, gain control over assets or win favors, nor should they accept } \\
\text { to be party to such practices in the course of their infrastructure } \\
\text { operations. }\end{array}$ & $\begin{array}{l}\text { Private sector chambers should develop } \\
\text { a code of conduct for the participation } \\
\text { in public infrastructure projects. }\end{array}$ \\
\hline 23 & $\begin{array}{l}\text { Private sector participants should contribute to strategies for } \\
\text { communicating and consulting with the general public, including vis-à- } \\
\text { vis consumers, affected communities and corporate stakeholders, with a } \\
\text { view to developing mutual acceptance and understanding of the } \\
\text { objectives of the parties involved. }\end{array}$ & $\begin{array}{l}\text { Private sector does not always play a } \\
\text { key role in promoting infrastructure } \\
\text { projects (APM Terminals' } \\
\text { communication strategy for the Moin } \\
\text { Container Terminal mark a positive } \\
\text { example). }\end{array}$ \\
\hline 24 & $\begin{array}{l}\text { Private sector participants in the provision of vital services to } \\
\text { communities need to be mindful of the consequences of their actions for } \\
\text { those communities and work, together with public authorities, to avoid } \\
\text { and mitigate socially unacceptable outcomes }\end{array}$ & $\begin{array}{l}\text { System overall does not promote a } \\
\text { trustful partnership between public and } \\
\text { private sector. }\end{array}$ \\
\hline
\end{tabular}

Source: Pisu and Villalobos (forthcoming). 


\section{Box 1. Policy recommendations}

Strengthen the institutional design to align policies and boost productivity by enhancing the strategic role of the Presidential Council on Competitiveness and Innovation, strengthening its technical unit and streamlining its organisation through merging its three different sub-councils.

\section{Improving links between foreign and domestic firms and encouraging innovation}

- Increase the share of public R\&D spending channeled to higher education institutions to strengthen links with local innovative enterprises and enhance job prospects for technical graduates.

- $\quad$ Scale up the programmes PROPYME and CR Provee and create a one-stop agency to manage and better coordinate them; swiftly approve the creation and establish the FOMPRODUCE agency.

- $\quad$ Continue efforts to better enforce intellectual property rights (IPRs) along with initiatives to strengthen

- $\quad$ awareness and the effective use of IPRs in universities and local firms.

\section{Enhancing competition, state-owned enterprises and access to finance}

- Improve the business environment by reducing barriers to entrepreneurship.

- Eliminate antitrust exemptions.

- Grant the competition commission more independence and the power to conduct market studies, and increase its financial resources.

- Introduce a leniency programme to encourage collaboration with competition authorities.

- Improve the governance of state-owned banks and enterprises by adopting the OECD Guidelines on Corporate Governance of State-owned Enterprises.

- Introduce a deposit-insurance scheme covering the whole banking sector and eliminate regulatory asymmetries favouring state-owned banks.

- After having improved the governance of state-owned banks and their efficiency levels, consider the opportunity of reducing government's equity stakes in banks and having a single state-owned bank with a clear public mandate.

- $\quad$ Adopt tariff-setting methodologies for regulated services encouraging productivity improvements.

\section{Improving transport infrastructure}

- To achieve better policy design and execution in transport and other infrastructure sectors, streamline the institutional and legal framework of public-works agencies, by reducing their number and better coordinate their policy and project-execution mandates.

- Establish a clear separation of SOEs' activities in the transport sector distinguishing between the regulation and the provision of infrastructure services and between the management of and access to the infrastructure network.

- Move the National Concession Council within the Ministry of Finance; start fully recording contingent liabilities arising from private participation in infrastructure.

- Define clear standards for cost-benefit analysis for infrastructure projects and start performing them.

- Define and update a clear and reliable infrastructure project pipelines. 


\section{REFERENCES}

Agénor, P. R., \& Moreno-Dodson, B. (2006), "Public Infrastructure and Growth: New Channels and Policy Implications", World Bank Policy Research Working Paper, No. 4064.

Anginer, D., A. Demirguc-Kunt, A., and \& M. Zhu, M. (2014), "How Does Deposit Insurance Affect Bank Risk? Evidence from the Recent Crisis", Journal of Banking \& Finance, Vol 48, 312-321. http://doi.org/10.1016/j.jbankfin.2013.09.013.

Arias, J.P. (2015), "Comisión de la Competencia se desintegra por discrepancias con Ministro de Economía", available at www.crhoy.com/comision-de-la-competencia-se-desintegra-pordiscrepancias-con-ministro-de-economia, accessed August 2015.

Banks, G. (2015), "Institutions to Promote Pro-Productivity Policies: Logic and Lessons", Paper presented to OECD Global Dialogue on the Future of Productivity in Mexico City, 6-7 July 2015, available at www.oecd.org/eco/growth/Institutions_to_Promote_Pro_Productivity_Policies_Logic_and_Lessons _revised_Banks.pdf.

Barth, J. R., G. Jr. Caprio., and R. Levine, R. (2004), "Bank Regulation and Supervision: What Works Best?", Journal of Financial Intermediation, Vol. 13(2), 205-248, http://doi.org/10.1016/j.jfi.2003.06.002.

Bouis, R. and R. Duval (2011), "Raising Potential Growth After the Crisis: A Quantitative Assessment of the Potential Gains from Various Structural Reforms in the OECD Area and Beyond", $O E C D$ Economics Department Working Papers, No. 835.

Bourlès, R. et al. (2010), "Do Product Market Regulations in Upstream Sectors Curb Productivity Growth: Panel Data Evidence for OECD Countries”, OECD Economics Department Working Papers, No. 791.

CAATEC (Comisión Asesora en Alta Tecnologia) (2014), Indice General de Costos Empresiarial, available at www.caatec.org/sitiol/igce.

CGR (Comptroller General of the Republic of Costa Rica) (2012). Memoria Anual 2011. San Jose, Costa Rica.

CGR (Comptroller General of the Republic of Costa Rica) (2014), Memoria Anual 2013. San Jose, Costa Rica.

Cheon, S., D.E Dowall, and S.W. Song (2010), "Evaluating Impacts of Institutional Reforms on Port Efficiency Changes: Ownership, Corporate Structure, and Total Factor Productivity Changes of World Container Ports", Transportation Research Part E: Logistics and Transportation Review, Vol. 46(4), 546-561. 
Cihak, M., A. Demirguc-Kunt, M.S.M. Peria, A. Mohseni-Cheraghlou (2012), "Bank Regulation and Supervision around the World : A Crisis Update", Policy Research working paper, No. WPS 6286. Washington, DC, World Bank, http://documents.worldbank.org/curated/en/2012/12/17039335/bank-regulation-supervisionaround-world-crisis-update.

CONAVI (Consejo Nacional de Vialidad) (2015), Informe de Evaluación Annual, available at www.conavi.go.cr.

Conway, P., D. de Rosa, G. Nicoletti, and F. Steiner (2006), "Regulation, Competition and Productivity Convergence", OECD Economics Department Working Papers, No. 509.

Dalberg (2011), Report on Support to SMEs in Developing Countries through Financial Intermediaries, Dalberg, Geneva, available at www.acp.int/sites/acpsec.waw.be/files/Dalberg_sme-briefingpaper.pdf.

de Luna-Martinez, D. and J.L. Vicente. (2012). "Global Survey of Development Banks", World Bank Policy Research Working Paper No. 5969.

Dell'Ariccia, G., E. Friedman and R. Marquez (1999), "Adverse Selection as a Barrier to Entry in the Banking Industry", The RAND Journal of Economics, 30(3), 515-534. http://doi.org/10.2307/2556061.

Demirgüç-Kunt, A. and H. Huizinga (1999). "Determinants of Commercial Bank Interest Margins and Profitability: Some International Evidence", The World Bank Economic Review, Vol. 13(2), 379408. http://doi.org/10.1093/wber/13.2.379.

Demirgüç-Kunt, A., A. Kane and L. Laevenet (2014), "Deposit Insurance Database", IMF Working, No. $14 / 118$.

Demirgüç-Kunt, A., 1. Laeven and R. Levine (2004). "Regulations, Market Structure, Institutions, and the Cost of Financial Intermediation", Journal of Money, Credit and Banking, Vol. 36(3), 593-622.

ECLAC (Economic Commission for Latin America and the Caribbean) (2014). Base de datos de inversiones en infraestructura económica en América Latina y el Caribe, 1980-2012. Santiago de Chile.

Égert, B. (2009), "Infrastructure Investment in Network Industries: The Role of Incentive Regulation and Regulatory Independence", CESifo Working Paper Series No. 2642.

Estache, A., B.T. de la Fe and L. Trujillo, L. (2004), "Sources of Efficiency Gains in Port Reform: a DEA Decomposition of a Malmquist TFP Index for Mexico", Utilities Policy, Vol. 12(4), 221-230.

Gereffi. G., P. Bamber, S. Frederick and K. Fernandez-Stark (2012), Costa Rica in Global Value Chains"AN Upgrading Analysis, Center on Globalization, Governance \& Competitiveness, Duke University, available at http://www.cggc.duke.edu/gvc/project.php?proj=180.

Griffith, R., S. Redding, and J.V. Reenen, J. V. (2004), "Mapping the Two Faces of R\&D: Productivity Growth in a Panel of OECD Industries, Review of Economics and Statistics, Vol. 86(4), 883-895. http://doi.org/10.1162/0034653043125194. 
Hausman, R., C.A. Hidalgo, S. Bustos, M. Coscia, A. Simoes and M. Yldirim (2014) The Atlas of Economic Complexity: Mapping Paths to Prosperity, The MIT Press.

IADB (Inter-American Development Bank) (2014), Synchronised Factories: Latin America and the Caribbean in the Era of Global Value Chains, Springer.

INCOFER (Instituto Costarricense de Ferrocarriles) (2014), Ficha Técnica del Proyecto: Sistema de Transporte Rápido de Pasajeros del Gran Área Metropolitana.

Irwin, T. (2007), Government Guarantees: Allocating and Valuing Risk in Privately Financed Infrastructure Projects, World Bank, Washington, DC.

Koske, I. et al. (2015), "The 2013 update of the OECD's database on product market regulation: Policy insights for OECD and non-OECD countries", OECD Economics Department Working Papers, No. 1200, OECD Publishing

La Porta, R., F. Lopez-De-Silanes and A. Shleifer (2002), "Government Ownership of Banks", The Journal of Finance, Vol. 57(1), 265-301, http://doi.org/10.1111/1540-6261.00422.

LANAMMEUCR (National Laboratory of Materials and Structural Models of the University of Costa Rica) (2015). Informe de Evaluación de la Red Vial Nacional Pavimentada de Costa Rica Años 2014-2015. San José, Costa Rica, available at http://www.lanamme.ucr.ac.cr/index.php/evaluaci\%C3\%B3n-red-vial-nacional-rv/informesevaluaci\%C3\%B3n-red-vial-nacional/informes-evaluaci\%C3\%B3n-red-vial-nacional,-a\%C3\%B1o2012-2014.html.

Manova, K. (2013), "Credit Constraints, Heterogeneous Firms, and International Trade", The Review of Economic Studies, Vol. 80(2), 711-744. http://doi.org/10.1093/restud/rds036.

Manova, K., S.-J.Wei and Z. Zhang (2014), "Firm Exports and Multinational Activity Under Credit Constraints", Review of Economics and Statistics, Vol. 97(3), 574-588. http://doi.org/10.1162/REST_a_00480.

McGowan A. ,M.D. Andrews, C. Criscuolo and G. Nicoletti (2015), The Future of Productivity, OECD, Paris.

Mirrlees-Black, J (2014), "Reflections on RPI-X Regulation in OECD Countries", CCRP Working Paper Series, No, 25, City University London.

Monge-González, R. and J.A. Rodríguez-Álvarez (2013), "Impact Evaluation of Innovation and Linkage Development Programs in Costa Rica: The Cases of PROPYME and CR Provee", IDB Working Paper Series, No. IDB-WP-461.

Monge-González, R., L. Rivera and J. Rosales-Tijerino (2010) "Productive Development Policies in Costa Rica: Market Failures, Government Failures, and Policy Outcomes", IDB Working paper Series, No IDB-WP-157.

MOPT (Ministry of Public Works) (2011). Plan Nacional de Infraestructura 2011-2035. San Jose, Costa Rica.

MOPT (Ministry of Public Works) (2014). Anuario Estadístico del Sector Transporte e Infraestructura 2013. San Jose, Costa Rica. 
MICITT (Ministry of Science, Technology and Telecomunicaciones) (2015), Indicadores Nacionales de Ciencia, Tecnología e Innovación, Costa Rica 2013, MICITT: San Jose

OECD (2006), Cost-Benefit Analysis and the Environment, OECD Publishing, Paris, http://dx.doi.org/10.1787/9789264010055-en.

OECD (2007), OECD Principles for Private Sector Participation in Infrastructure, OECD Publishing, Paris, http://dx.doi.org/10.1787/9789264034105-en

OECD (2010a), Dedicated Public-Private Partnership Units. A Survey of Institutional and Governance Structures, OECD Publishing, Paris, http://dx.doi.org/10.1787/9789264064843-en.

OECD (2010b), Roundtable on Competition, Concentration and Stability in the Banking Sector, Paris: OECD Policy Roundtables, http://www.oecd.org/competition/sectors/46040053.pdf.

OECD (2011), Bank Competition and Financial Stability, OECD Publishing, Paris, http://dx.doi.org/10.1787/9789264120563-en.

OECD (2012), Competitive Neutrality: Maintaining a Level Playing Field between Public and Private Business, OECD Publishing, Paris, http://dx.doi.org/10.1787/9789264178953-en.

OECD (2013), OECD Investment Policy Reviews: Costa Rica 2013, OECD Publishing, Paris, http://dx.doi.org/10.1787/9789264203952-en.

OECD (2014a), Competition Law and Policy in Costa Rica: A Peer review, OECD Publishing, Paris, http://www.oecd.org/daf/competition/CostaRica-PeerReview2014en.pdf.

OECD (2014b), How's Life?, OECD Publishing, Paris, http://dx.doi.org/10.1787/how_life-2015-en

OECD (2014c), How's Life in Your Region?: Measuring Regional and Local Well-being for Policy Making, OECD Publishing, Paris, http://dx.doi.org/10.1787/9789264217416-en

OECD (2014d), OECD Science, Technology and Industry Outlook 2014, OECD Publishing, Paris, http://dx.doi.org/10.1787/sti_outlook-2014-en.

OECD (2015a), Building on Basics: Value for Money in Government, OECD Publishing, Paris, http://dx.doi.org/10.1787/9789264235052-en.

OECD (2015b), Competition and Market Studies in Latin America: The Case of Chile, Colombia, Costa Rica, Mexico, Panama and Peru, OECD Publishing, Paris, http://www.oecd.org/daf/competition/competition-and-market-studies-in-latin-america2015.pdf.

OECD (2015c), OECD Guidelines on Corporate Governance of State-owned Enterprises, OECD Publishing, Paris, http://dx.doi.org/10.1787/9789264244160-en.

OECD (2015d), Market Openness Review of Costa Rica, OECD Publishing, Paris.

OECD (2015e), “OECD Innovation Strategy 2015: An agenda for Policy Action”, Meeting of the OECD Council at Ministerial Level Paris, 3-4 June 2015, http://www.oecd.org/sti/OECD-InnovationStrategy-2015-CMIN2015-7.pdf. 
OECD (2015f), The Innovation Imperative, OECD Publishing, Paris, http://dx.doi.org/10.1787/9789264239814-en.

OECD (2015g), "The Future of Productivity", Joint Economics Department and the Directorate for Science, Technology and Innovation Policy Note, July 2015, http://www.oecd.org/eco/growth/Thefuture-of-productivity-policy-note-July-2015.pdf.

OECD (2015h), OECD Economic Outlook Database, OECD, Paris, http://dx.doi.org/10.1787/bd810434en.

OECD (2016), OECD Economics Survey: Costa Rica, 2016, OECD Publishing, http://dx.doi.org/10.1787/eco_surveys-cri-2016-en

Persson, J. and D. Song (2010), “The Land Transport Sector: Policy and Performance", OECD Economics Department Working Papers, No. 817, OECD Publishing.

Pisu M. and F. Villalobos (forthcoming), "Costa Rica's Infrastructure Challenge", OECD Economics Department Working Paper, OECD Publishing, Paris.

Pisu, M., P. Hoeller and I. Joumard (2012), "Options for Benchmarking Infrastructure Performance", OECD Economics Department Working Papers, No. 956, OECD Publishing Paris.

Posner, P., S.K. Ryu and A. Tkachenko (2009), "Public-Private Partnerships: The Relevance of Budgeting”, OECD Journal on Budgeting, Vol. 9(1), 41-66.

Pisu, M. Pels and Bottini (2015), "Improving Infrastructure in the United Kingdom", OECD Economic Department Working Paper, No. 1244.

Sappington, D. E. M. and D.L. Weisman (2010), "Price Cap Regulation: What Have We Learned from 25 years of Experience in the Telecommunications Industry?", Journal of Regulatory Economics, Vol. 38(3), 227-257.

Siemiatycki, M. (2013), "The Global Production of Transportation Public-Private Partnerships", International Journal of Urban and Regional Research, Vol. 37(4), 1254-1272.

Stutzer, A., and B.S. Frey (2008), "Stress that Doesn't Pay: The Commuting Paradox". Scandinavian Journal of Economics, Vol. 110(2), 339-366.

SUTEL (Superintendencia de Telecomunicaciones) (2015), Estadísticas del sector de Telecomunicaciones, available at http://sutel.go.cr/sites/default/files/estadisticastelecomsutel2014baja_0.pdf

World Bank (2012). Global Development Indicators 2011. The World Bank Group: Washington.

World Bank (2013), Global Financial Development Report 2013, The World Bank Group: Washington. 